FOLIA HISTORICA CRACOVIENSIA, 22: 2016, s. 233-264

DOI: http://dx.doi.org/10.15633/fhc.2081

Urszula Mazurczak

Katolicki Uniwersytet Lubelski Jana PawŁa II

\title{
Związki teologii krzyża św. Bonawentury \\ z mistyką Karmelu. \\ Z kręgu powinowactwa sztuki franciszkańskiej \\ i karmelitańskiej na wybranych przykładach \\ sztuki z XIV i początku XV wieku
}

Badania historii zakonu ojców karmelitów, a także duchowości i zasług w religijnym i naukowym dziedzictwie Europy stanowią ogromny dorobek życia naukowego śp. ojca prof. Benignusa Wanata. Wpisany jest on do klasyki literatury dotyczącej zakonu oraz jego sztuki ${ }^{1}$. Zasługi ojca profesora dla wyjaśnienia i zaprezentowania historii zakonu, a szczególnie historii i bogatej spuścizny sztuki w Polsce, inspirują do dalszych szczegółowych poszukiwań, których rezultatem jest niniejsza praca ${ }^{2}$. W literaturze naukowej na temat plastyki karmelitańskiej, jej stylu, a przede wszystkim założeń ikonograficznych decydującą przewagę mają rozprawy z zakresu mariologii, co jest zrozumiałe w kontekście nazwy zakonu Zakon Braci Najświętszej Maryi Panny z Góry Karmel - oraz głównego nurtu przyjętej pobożności od momentu jego powstania ${ }^{3}$. Ojciec Wanat uporządkował

Zob. B. Wanat, Zakon Karmelitów Bosych w Polsce. Klasztory karmelitów i karmelitanek bosych 1605-1975, Kraków 1979; B. Wanat, Zakon Karmelitów Bosych w Polsce, t. 1-2, Kraków 1988.

2 Monografie szczegółowe na temat Matki Bożej Szkaplerznej, św. Józefa oraz architektury konkretnych założeń karmelitów włączają książki o. B. Wanata do gruntownej literatury z zakresu historii sztuki barokowej w Polsce. Zob. J. Smet, Historia Zakonu Braci Najświętszej Maryi Panny $z$ Góry Karmel, t. 1-4, Kraków 1986.

3 Zob. A. Baudrillart, Dictionnaire d'histoire et de géographie ecclésiastiques, vol. 11, Paris 1949, col. 1070-1104; Karmelita Bosy, Ideał $i$ duch Karmelu, przekład z francuskiego, wyd. M.R.K.B., Kraków 1946; R. Róg, Karmelici. Duchowość. Historia, Kraków 1997; J. Zieliński ocD, Herb Karmelu. Historia, symbolika, duchowe przesłanie, Kraków 2001; C. Gilbert, Some special images for carmelites, [w:] Image and Religions, eds. T. Verdon, J. Handerson, New York 1990, s. 78. 
materiał zabytkowy, dotarł do jego źródeł oraz wyjaśnił zagadnienia historyczne, stylowe i ikonograficzne sztuki karmelitów w Polsce okresu nowożytnego ${ }^{4}$. Literatura zarówno obca, jak i polska podejmuje badania wątków chrystologii, hagiografii oraz wielu symboli, które związane są z dekoracją architektoniczną i wystrojem plastycznym architektury kościelnej i klasztornej. Ikonografię sztuki średniowiecznej karmelitów określiły w dotychczasowych badaniach dostrzegane związki z zakonem i duchowością dominikanów oraz ikonografią maryjną. Podtrzymują to źródła, pisma wielkich mistyków oraz badania karmelu w okresie nowożytnym. Jednak pobożność i kontemplacja mistyczna, przekazana w pismach mistyków karmelu doby nowożytnej, określa krzyż jako podłoże całej duchowości, co ma swoje odbicie w sztuce ${ }^{5}$.

Postawione $\mathrm{w}$ tytule zagadnienie badawcze, mające swoje podstawy $\mathrm{w}$ rozważaniu Krzyża Chrystusa w formie Drzewa Życia, sformułowane w teologii św. Bonawentury, ukierunkowane jest na poszukiwanie związków z franciszkańską pobożnością oraz jej odzwierciedleniem w sztuce. Ten kierunek badań nie był do tej pory podejmowany jako odrębne studium, w tym miejscu również nie rozwiążemy problemów, które wystarczająco ten temat wyjaśniłyby ${ }^{6}$. Wyobrażenia Ukrzyżowania w sztuce karmelitańskiej na terenach Rzeczypospolitej, które zebrał i poparł gruntownymi źródłami, a także podstawami historycznymi w swoich książkach ojciec Wanat, wskazują, że w polskiej spuściźnie zachowane są przedstawienia świętych franciszkańskich, których liczne wizerunki np. św. Franciszka, św. Klary, św. Bonawentury - mimo zawirowań historii, przechowały kościoły i klasztory karmelitańskie. Większość z nich pochodzi z czasu największego rozkwitu i oddziaływania religijnego i kulturowego karmelu? ${ }^{7}$.

4 Zob. B. Wanat, Matka Boska Szkaplerzna w Czernej, Kraków 1988. Monografia dotycząca klasztorów karmelitów i karmelitanek w Polsce jest porównawczym studium do poszukiwania inspiracji z wcześniejszymi, średniowiecznymi wątkami ikonograficznymi.

5 A. Baudrillart, Dictionnaire d'histoire..., dz. cyt., podaje najwcześniejsze źródła dotyczące duchowości karmelu w średniowiecznej Europie. W literaturze polskiej zob. prace B. Wanata (zob. przypisy $1-2$ i 4 ).

Słabo podejmowany, nie znaczy nieistniejący; zob. A. Baudrillart, Dictionnaire d'histoire..., dz. cyt., passim oraz historyczne studia, które wskazują na spotkanie franciszkańskich zakonników z eremitami w Palestynie przed ich przybyciem do Europy. Por. Sz. T. Praśkiewicz, Duchowość Maryjna w Świętym Karmelu, Poznań 2011.

Zob. H. Bieniarzówna, A. Piotrowski, Sanktuarium Maryjne w kościele O. Karmelitów na Piasku, Kraków 1983; B. Wanat, Zakon Karmelitów Bosych w Polsce. Klasztory karmelitów i karmelitanek..., dz. cyt., passim. Cenne są rozprawy: T. Trajdos, Fundacja Klasztoru Karmelitów Trzewiczkowych pw. Bożego Ciała w Poznaniu. Kult Eucharystyczny króla Władysława Jagiełty, „Po- 
Ikonografia krzyża w pobożności i sztuce franciszkańskiej została szczegółowo opracowana. Wskazano na specyficzną formę krzyża jako drzewa życia, powstałą w tym kręgu ${ }^{8}$. Jednak początki tego rodzaju przedstawienia wskazują na Palestynę i - szerzej - wschodni obszar wczesnego chrześcijaństwa, na co zwracali uwagę wybitni mediewiści ${ }^{9}$. Stamtąd przybyli do Europy karmelici, w kręgu tego zakonu utrwalił się ten model krzyża w piśmiennictwie i w wyobrażeniach nowożytnych. Zajmiemy się tu okresem średniowiecza, kiedy swój etos kształtował zakon karmelitów w Europie. Interesuje nas ugruntowanie się krzyża jako Lignum Vitae, znanego we wczesnych formach wschodnich w wiekach IV-VII, stającego się programem w sztuce franciszkańskiej. Poszukujemy wzajemnej osmozy franciszkanów i karmelitów na terenie Italii zarówno w pobożności, jak i w sztuce. Za podstawę wyjaśnienia wyobrażeń krzyża jako Drzewa Życia przyjmujemy teksty św. Bonawentury, ponieważ w dojrzałym średniowieczu był on teologiem cieszącym się wielkim autorytetem nie tylko wśród franciszkanów, ale i w Kościele powszechnym. Jego teksty są klarowne w rozumieniu pobożności popularnej, a także ówczesnych kręgów akademickich. Był kardynałem, profesorem, powiernikiem papieża w ważnych sprawach Kościoła, a zarazem rozmodlonym mistykiem.

W poszukiwaniu wczesnych powinowactw życia i duchowości karmelickiej i franciszkańskiej, w tym formy krzyża Lignum Vitae, konieczne jest krótkie przypomnienie najważniejszych faktów historycznych dotyczących pochodzenia karmelu. Zakon Najświętszej Maryi Panny wywodzi się z Palestyny, z rejonu góry Karmel, wznoszącej się w pobliżu portu Hajfa, miejsca życia proroka Eliasza. Księga Królewska w wersji Wulgaty daje przekaz o potoku Kerit na wschód od Jordanu, z którego Eliasz czerpał wodę (1 Krl 17, 3-5). Tutaj Bóg odwrócił

znańskie Studia Teologiczne" 5 (1984); T. Trajdos, U zarania Karmelitów w Polsce, Warszawa 1993; R. Róg, Karmelici. Duchowość..., dz. cyt.; K. Płonka-Bałus, Antyfonarz z roku 1397 w Bibliotece oo. Karmelitów na Piasku w Krakowie. Ze studiów nad iluminatorstwem czeskim przełomu XIV $i$ XV wieku, „Folia Historiae Artium” 27 (1981), s. 35-6o.

8 Zob. T. Borenius, An Early Sienense crucifixion, „Burlington Magazine” 56 (1930), s. 123-156.

9 Źródłowy przekaz zob. Itineraria Hierosolymitana et descriptiones Terrae Sanctae, vol. 1, a cura di T. Tobler, A. Molinier, Geneve 1870, s. 126; Itineraria Hierosolimitana, saeculi IV-VIII, a cura di P. Geyer, Vindobonae 1898, s. 172-173; H. Leclercq, Ampoules a eulogies, [w:] Dictionnaire d'Archéologie Chrétienne et Liturgie, vol. 2, Paris 1924, col. 1722-1747; A. Colombo, Le ampolle metalliche della basilica di Monza, „Rivista di Monza” 1937, s. 21-31; A. Grabar, Les Ampoules de Terre Sainte Monza-Bobbio, Paris 1938; A. Grabar, Ampoules de Terre Sainte, „Zeitschrift für Kunstgeschichte" 51 (1988), s. 34-56; K. Weitzmann, Loca Sancta and the representational arts of Palestine, „Dumbarton Oaks Papers” 28 (1974), s. 32-55. 
klęskę suszy i objawił mu nadejście życiodajnego deszczu $(1 \mathrm{Krl} 18,42)^{10}$. W Septuagincie w Trzeciej Księdze Królewskiej Karmel jest pasmem wzgórz naprzeciw Jordanu, dochodzącym w Samarii do Morza Śródziemnego ${ }^{11}$. Tutaj na górze Karmel miał się zgromadzić lud Izraela wierny Bogu (1 Krl 18, 19-20). Miejsce to, związane z życiem proroka Eliasza, zamieszkiwane było od III wieku przez pustelników zwanych karmelitami ${ }^{12}$. Powstanie zakonu wiąże się $\mathrm{z}$ okresem wojen krzyżowych w XII wieku, wtedy wymieniany jest w itinerariach podróżników, np. z roku 1165 rabina Benjamina z Tudeli czy nieco późniejszy z roku 1185 greckiego mnicha Jana Phocasa ${ }^{13}$. Opisy niezwykle malowniczego usytuowania klasztoru, nad urwiskiem skalnym, tuż nad morzem, przedstawiają grotę oraz źródło proroka Eliasza. Wymieniane są ruiny wczesnej budowli, być może kaplicy, która potwierdza powstałe w tym miejscu zalążki form życia monastycznego. Życie mnichów na górze Karmel ożywione zostało w XIII wieku. Z tego czasu, z roku 1220, pochodzi przekaz Jakuba de Vitry, biskupa Ptolemajdy, który, widząc pustelnie mnichów, opisał ich styl życia na wzór świętego proroka. Ich mieszkaniem były niewielkie groty w pobliżu źródła Eliasza, gdzie przebywali, „jak mistyczne pszczoły wytwarzając miód Bożej kontemplacji”" ${ }^{14}$. W tym porównaniu mnichów do pszczół ujawnia się znajomość tekstów św. Ambrożego, biskupa Mediolanu. Zakonne życie wspólnotowe organizowane było stopniowo, nie niwecząc wczesnych form pustelniczych.

Istotną rolę odegrali krzyżowcy, szczególnie św. Brokart (Jan de Malins), który w roku 1209 wyjednał u patriarchy jerozolimskiego Alberta Avogardo regułę życia, zatwierdzoną w roku 1226 przez papieża Honoriusza II bullą Ut vivendi normam, następnie potwierdzoną w roku 1229 przez papieża Grzegorza IX ${ }^{15}$. Papież ten przyjął zakon pod opiekę Stolicy Apostolskiej ${ }^{16}$. Oprócz klasztoru „przy źródle św. Eliasza" karmelici posiadali na terenie Palestyny inne domy. Według przekazu Wilhelma de Sanvicko, żyjącego w drugiej połowie xIII wieku, znane były siedziby w Sarepcie (również związanej z prorokiem Eliaszem), w Akrze,

10 Pismo Święte Starego i Nowego Testamentu w przekładzie z języków oryginalnych, oprac. zespół biblistów polskich z inicjatywy Benedyktynów Tynieckich, Warszawa 1971, s. 331.

${ }^{11}$ Septuaginta czyli Biblia Starego Testamentu wraz $z$ ksieggami deuterokanonicznymi i apokryfami, tłum., przypisy i wstęp ks. R. Popowski, Warszawa 2014, s. 479-478.

12 A. Baudrillart, Dictionnaire d'histoire..., dz. cyt., col. 1070-1071.

13 A. Baudrillart, Dictionnaire d'histoire..., dz. cyt., col. 1070-1071.

${ }^{14}$ Hist. Orientalis Hierosolimitana, za: A. Baudrillart, Dictionnaire d'histoire..., dz. cyt., col. 1070.

15 Zob. A. Baudrillart, Dictionnaire d'histoire..., dz. cyt., col. 1073.

16 Zob. A. Baudrillart, Dictionnaire d'histoire..., dz. cyt., col. 1073. 
Tyrze, Trypolisie, Antiochii i Jerozolimie, na Pustyni Czterdziestodniowego postu Chrystusa ${ }^{17}$.

W wyniku inwazji tureckiej na Palestynę przełożony generalny Alan z Bretanii podjął decyzję o ewakuacji zakonników do Europy, zakładając pierwsze domy już w latach 30. XIII wieku we Frontino na Cyprze i na Sycylii ${ }^{18}$. Około połowy XıII wieku mnisi zaczęli przenosić się w małych grupach do środkowej i północnej Italii. Osiedlali się również w południowej Francji, na pustyni koło Marsylii, w roku 1241 dotarli nawet do północnych krańców kontynentu: Anglii, Hulme i Aylesford. Ostatni klasztor karmelitów w Palestynie zniszczony został przez Turków w roku 1291, co całkowicie zakończyło ich życie w tym miejscu ${ }^{19}$. Trzeba jednak podkreślić, że ten okres działalności zakonników, mimo surowości reguły i braku środków materialnych, pozostawił trwały ślad w ich duchowości, medytacji i modlitwy, co przynieśli do Europy.

Palestyna i Wschód, zwłaszcza Egipt, były także miejscem wyrobu drobnej plastyki: krzyży, relikwiarzy, naczyń, skrzynek na ziemię świętą, wykonywanych $\mathrm{z}$ materiałów kosztownych, a także z tanich, np. wypalanej gliny. Dewocjonalia te i wota były przenoszone do różnych regionów, w tym do Europy, i nabywane w miejscach świętych - loca sancta. Szczególne znaczenie miały ampułki na oliwę z grobu Chrystusa, którą przekazywano kościołom. Ikonografia na tych przedmiotach, jak już zostało to przebadane w wizerunkach Chrystusa i Maryi, ma znaczenie modelowe (il. 1-2) ${ }^{20}$, wyrażone m.in. w przedstawieniach krzyży w formie Drzewa Życia. Karmelici jako ubodzy pustelnicy, potem zakonnicy, znali te przedmioty i identyfikowali z konkretnymi miejscami świętymi, przy których żyli na terenie Ziemi Świętej. Jak dużo tych przedmiotów przywieźli do Europy, nie wiadomo. Surowa reguła zabraniała posiadania rzeczy osobistych, nawet dewocjonaliów, były jednak w użytku grupy modlitewnej, potem zakonnej, w kościołach czy kaplicach. Karmelici formę krzyża - Drzewa Życia znali jednak dobrze, jeszcze zanim przybyli do Europy.

Historycy zakonu podkreślają trudne początki odnajdywania się zakonników w nowym środowisku, w Europie w połowie xıII wieku. Były to czasy

${ }_{17}$ Zob. A. Baudrillart, Dictionnaire d'histoire..., dz. cyt., col. 1073.

18 Zob. A. Baudrillart, Dictionnaire d'histoire..., dz. cyt., col. 1073.

19 Zob. A. Baudrillart, Dictionnaire d'histoire..., dz. cyt., col. 1073.

${ }^{20}$ Zob. A. Grabar, Les Ampoules..., dz. cyt.; K. Weitzmann, Loca Sancta..., dz cyt.; T. Dobrzeniecki, Legenda o Secie i drzewie życia w sztuce średniowiecznej, „Rocznik Muzeum Narodowego w Warszawie” 10 (1966); T. Dobrzeniecki, Maiestas Domini w zabytkach polskich i obcych z Polska związanych, „Rocznik Muzeum Narodowego w Warszawie” 17 (1973), s. 64nn. 
silnej urbanizacji obszarów niezagospodarowanych, migracji do miast, nowatorskiego stylu w budownictwie, intensywnego gromadzenia kapitału, wszystko to w warunkach systemu feudalnego. Były to czasy autentycznego rozwoju w nauce na różnych poziomach kształcenia i studiów. Intensywnie rozwijały się różne formy kultury, zapomniane od czasów antycznych, np. teatr, widowiska religijne, literatura dworska. Można mieć wątpliwości co do stopnia szybkiej asymilacji pustelników w ludnych i bogacących się środowiskach miast.

Osiedlając się w środkowej części Apenin, karmelici spotykali się z rodzimym stylem życia. W małych grupach żyli bracia franciszkanie w Umbrii w okolicach Tugurio de Rivotorto, niedaleko wzgórza Matki Bożej Anielskiej, miejsca źródeł rzek Chiscio i Tybru, w bezludnych okolicach Apenin zwanych Cytadelą Boga albo Nowym Jeruzalem. Ich eremy w pobliżu Rieti, w dolinie Rietiny, w okolicy Greccio nazywano więzieniami Boga (delle carceri). W tych słabo zaludnionych, wręcz dzikich częściach Apenin żyli, razem z franciszkańskimi wspólnotami eremickimi, także kameduli i wallombrozjanie ${ }^{21}$. Jak potwierdzają badania pierwotnej formy architektury i zabudowań franciszkanów - przed ukończeniem bazyliki św. Franciszka w Asyżu (dolnej w roku 1230, górnej w 1253 i poświęconej przez papieża Innocentego IV) - życie tego zakonu miało jeszcze cechy eremickie, skupiało się w obrębie niewielkich orsetto, orso, dosłownie: szop ${ }^{22}$. Potrzeba wspólnej liturgii powodowała intensywną pracę nad przywróceniem zrujnowanych pozostałości do prostych, funkcjonalnych kaplic, oratoriów, czego przykładem jest pierwszy kościół San Damiano, odbudowany przez św. Franciszka. Zakonnicy zagospodarowywali porzucone stajnie i inne pomieszczenia gospodarcze. W tej prostocie życia franciszkańskiego karmelici postrzegali własny styl życia, który pozostawili w Palestynie. Spotkanie duchowości franciszkańskiej z karmelitańską podyktowało zatem samo życie, na długo przed sformułowaniem programu kształcenia na poziomie akademickim. Współistnienie karmelitów z franciszkanami w obrębie pierwotnych ubogich wspólnot przetrwało, gdy organizowane były w miastach klasztory dla posługi duszpasterskiej. Wskazują na to lokacje kościołów franciszkańskich i karmelickich w centralnych częściach takich miast, jak na przykład: Piza, Siena, Florencja, Arezzo, Perugia, Viterbo, Cività Vecchia czy Bolonia. W drugiej połowie XIII i w wieku XIV nawet w mało

${ }_{21}$ Zob. H. Romanini, Il Medioevo. Storia dell'Arte Italiana, vol. 2, Firenze 1988, passim.

${ }_{22}$ Zob. H. Romanini, Assisi, [w:] Enciclopedia dell'arte Medievale, vol. 1, Roma 1989 (tamże obszerna literatura przedmiotu). 
zagospodarowanych pod względem życia miejskiego prowincjach, jak Tuscia, $\mathrm{w}$ roku 1333 odnotowano aż 12 domów zakonnych ${ }^{23}$.

Karmelici, przystępując w Europie do działalności duszpasterskiej, rozpoczęli czynne uczestnictwo $\mathrm{w}$ życiu naukowym. Wskazuje to na związek $\mathrm{z}$ dominikańską nauką i teologią, co przetrwało jeszcze w nowożytnej historii zakonu w duchowości wielkich mistyków ${ }^{24}$. Jednakże zarówno w Italii, jak i w wielu ośrodkach europejskich pod koniec XIII wieku następował proces asymilacji nauki franciszkańskiej i dominikańskiej, co miało miejsce i w szkołach katedralnych, i na uniwersytetach oraz studiach generalnych ${ }^{25}$. Papież Innocenty IV, na prośbę ówczesnego generała św. Szymona Stocka, zmodyfikował regułę życia zakonnego karmelitów, dostosowując ją do nowych uwarunkowań w Europie ${ }^{26}$.

Święty Szymon Stock zatwierdził na kapitule generalnej w Londynie w roku 1281 pierwsze listy studentów zakonu, co kontynuował ojciec Gerard z Bolonii, mający już tytuł magistra teologii ${ }^{27}$. Będąc przeorem generalnym w latach 1287-1317, ujednolicił on program studiów. Napisał Summę teologiczną, która - zdaniem znawców - nawiązuje do Summy Doktora Anielskiego - św. Tomasza z Akwinu ${ }^{28}$. Na początku XIV wieku karmelici studiowali we Florencji, w Bolonii, Neapolu, Mediolanie, a także poza Italią - w Paryżu Tuluzie, Montpellier i w Kolonii. Ukończone stopniem naukowym studia były warunkiem wyboru przełożonego generalnego. Jest w tej historii tworzenia własnego etosu naukowego ważny fakt, że pod koniec XIII i w wieku XIV program studiów teologicznych obejmował zarówno dominikańskie, jak i franciszkańskie autorytety, stanowiące o najważ-

${ }^{23}$ Zob. A. Sabatini, Origini e Antichità della Provincia Toscana dei Carmelitani, „Analecta Ordinis Carmelitanum" 16 (1949), s. 183-220.

${ }^{24} \mathrm{~W}$ zakresie sztuki związek ten po raz pierwszy analizuje F. Saxl (A spiritual encyclopedia of the Later Middle Ages, "Journal of the Warburg and Courtauld Institutes" 5 [1942], s. 82-134). Dla średniowiecza i okresu nowożytnego literatura jest obszerna: Karmelita Bosy, Ideat $i$ duch Karmelu, dz. cyt.; jako przykład w mistyce Jana od Krzyża: Jan od Krzyża doktor Kościoła, Droga na Górę Karmel. Noc ciemna. Żywy płomień miłości. Pieśń duchowa, Kraków 1999. Interpretacja zob. ks. K. Wojtyła, Zagadnienie wiary w dziełach św. Jana od Krzyża, [w:] Jan Paweł II o świętych Karmelu, przygot. Cz. Gil ocD, Kraków 1986, s. 23nn.

${ }_{25}$ Zob. E. Gilson, Historia filozofii chrześcijańskiej w wiekach średnich, tłum. S. Zalewski, Warszawa 1966; F. Van Steenberghen, Filozofia wieku XIII, tłum. I. Zieliński, Lublin 1991.

${ }^{26}$ Zob. B. Wanat, Zakon Karmelitów Bosych w Polsce, t. 1, dz. cyt., s. 34.

${ }_{27}$ Zob. B. Wanat, Zakon Karmelitów Bosych w Polsce, t. 1, dz. cyt., s. 34.

${ }_{28}$ Zob. B. Faes de Mottoni, L'Illusione dei sensi? Angeli e sensi in Bonaventura e in Tommaso d'Aquino, „Micrologus. Natura, Scienze e Società Medievali” 10 (2002), s. 294-312. 
niejszych dogmatach wiary. Wykłady z teologii dotyczyły zarówno św. Tomasza z Akwinu, Alberta Wielkiego, Bernarda z Clairvaux, jak i Bonawentury, a później Dunsa Szkota ${ }^{29}$.

W badaniach nad dorobkiem filozoficznym i teologicznym św. Bonawentury (Giovanni da Fidanza, 1221-1274) podkreśla się jego przemyślaną i dojrzałą osmozę arystotelizmu chrześcijańskiego św. Tomasza z Akwinu z augustiańską szkołą teologiczną, w której wyrastał wraz ze św. Franciszkiem późniejszy kardynał ${ }^{30}$. Te dwa systemy przeszły również do nowożytności i zakorzeniły się w mistyce karmelitańskiej. W xv wieku zakon miał własnych uczonych: Jana Bacontropa, Michała z Bolonii i Tomasza Waldensa.

Religijność i duchowość karmelu w jego fazie prostego palestyńskiego eremityzmu przesiąknięta była czcią do Matki Bożej, na niej wyrastał św. Szymon Stock i na niej osadzona została tradycja szkaplerza karmelitańskiego. Ten nurt jest szeroko opracowany także w ikonografii sztuki ${ }^{31}$. Ziemia Święta w okresie wczesnych zasiedleń karmelitów w Palestynie była szczególnym miejscem czczonym ze względu na Pasję Chrystusa. W życiu zakonnym w średniowieczu łacińskim Wcielenie i mistyka krzyża były ze sobą ściśle zjednoczone. U podstawy religijnej praktyki, modlitwy, medytacji skupiona była duchowość benedyktynów, cystersów i franciszkanów, jednocześnie w żadnym z tych kręgów monastycznych nie pomniejszano roli Maryi Dziewicy. Kulminacją zjednoczenia z Ukrzyżowanym Chrystusem były stygmaty św. Franciszka (1181-1226), które uzmysławiały wiernym zjednoczenie z Ukrzyżowanym w realnym życiu człowieka. W kazaniach i pismach św. Antoniego z Padwy ciało narodzonego Jezusa jako rezultat dziewiczego Wcielenia jest nierozdzielnie złączone z ciałem umęczonym i umarłym na krzyżu ${ }^{32}$. Jednak krzyż Męki jest zarazem Krzyżem Życia. Takie pojęcia i tropy, znane w modlitwach i rozważaniach franciszkańskich, prowadzą

29 Zob. K. Ruth, Bonaventura, Köln 1956; E. Gilson, Die Philosophie des hl. Bonaventura, Freiburg 1960.

${ }_{30}$ Zob. L. Veuthey of mConv, Filozofia chrześcijańska św. Bonawentury, tłum. E. I. Zieliński of MConv, Niepokalanów 1996; E. Zieliński, Interpretacje filozofii św. Bonawentury, [w:] Św. Bonawentura. Życie i myśl, red. C. Napiórkowski, I. Zieliński, Warszawa 1976, s. 78-96.

${ }_{31}$ Zob. B. Wanat, Matka Boska Szkaplerzna..., dz. cyt.; G. Monaco, Santa Maria del Carmine detta „La Bruna”, Naples 1975, s. 27-30.

${ }^{32}$ Zob. V. Gambosco, Per conoscere sant'Antonio. La vita - Il pensiero, Padova 199o. Fundamentalne badania nad ikonografią św. Franciszka w kontekście pobożności franciszkańskiej i filozofii św. Bonawentury zob. Ch. Frugoni, Francesco e l'invenzione delle stimmate. Una storia per parole e immagini fino a Bonaventura e Giotto, Torino 1993. 
do wschodniej, palestyńskiej kontemplacji wczesnego chrześcijaństwa. Nie były one obce $\mathrm{w}$ życiu pustelniczym eremitów z góry Karmel ${ }^{33}$.

W naszej pracy koncentrujemy się na wybranych zagadnieniach teologii krzyża według św. Bonawentury, ponieważ ten teolog i filozof stworzył klarowną syntezę interpretacji krzyża w kontekście Stworzenia, Wcielenia i Zmartwychwstania. Jednocześnie pisma te nie były encyklopedycznym zbiorem znanych wykształconemu kardynałowi tekstów z kręgu patrystyki wschodniej i zachodniej. Odpowiadały na zapotrzebowanie scholastyki, która poszukiwała zjednoczenia wiary $\mathrm{z}$ rozumem; $\mathrm{w}$ tym sensie bliskie są związki zarówno $\mathrm{z}$ arystotelizmem chrześcijańskim, jak i tomizmem. Interpretacje Boga i świata św. Bonawentury pozostają oryginalne dzięki mistrzowi, św. Franciszkowi, który uczył zbratania się $\mathrm{z}$ naturą, przyrodą $\mathrm{w}$ radosnej rozmowie $\mathrm{z}$ ptakami albo $\mathrm{z}$ bratem wilkiem. Poznanie rozumowe i wiara leżą u podstawy krzyża, którego żywotność porównywana jest do krzewu winnego i do kwitnącego drzewa ${ }^{34}$. Teksty św. Bonawentury, zarówno mistyczne, jak i komentarze, znane były w szerokim odbiorze pobożności zakonnej i w ambitnych studiach uniwersyteckich. Przenikanie pism Bonawentury do środowisk wschodnich, palestyńskich, zostało już wykazane w, nielicznych co prawda, jednak istotnych badaniach. Franciszek Bonacursus (młodszy brat we wspólnocie franciszkańskiej św. Bonawentury) w roku 1272, będąc arcybiskupem Tyru, znał i rozpowszechniał w tamtym środowisku pisma mistrza na dwa lata przed jego śmiercią ${ }^{35}$. Prototypami Chrystusa we wczesnochrześcijańskich egzegezach teologicznych byli prorocy Eliasz i Elizeusz, mieszkający na górze Karmel. Szczegółowo podjęte studia potwierdzają ścisły związek krzyża z Drzewem Życia, który propagowany był wraz z kultem Maryi w pobożności karmelitów żyjących w Palestynie ${ }^{36}$. Porównawcze studium teologii krzyża św. Bonawentury w nowożytnym karmelu pozostawiamy autorytatywnym badaczom. W tym miejscu karmel został przypomniany z racji jego palestyńskiej genezy i tamtych pierwszych wzorów krzyża w typie arbor crucis.

Święty Bonawentura, zwany Doktorem Serafickim, podjął w swojej teologii krzyża syntezę Księgi Rodzaju, stworzenia Adama i Ewy, z Odkupieniem

${ }_{33}$ Zob. R. Hendriks o.carm, La Succession hereditaire Elie le prophete, Bruges 1956, s. 34-89; B. Wanat, Zakon Karmelitów Bosych w Polsce. Klasztory karmelitów i karmelitanek..., dz. cyt., passim.

${ }^{34}$ Nowe życie w Chrystusie, tłum. K. Żuchowski ofmbern, [w:] Św. Bonawentura, Pisma teologiczno-ascetyczne, Warszawa 1978, s. 303-311.

35 Zob. F. Saxl, A spiritual encyclopedia..., dz. cyt.

${ }^{36}$ Zob. R. Hendrics O.carm, La Succession..., dz. cyt., passim. 
i Zmartwychwstaniem Chrystusa ${ }^{37}$. W Breviloquium krzyż jest rozumiany w znaczeniu symbolicznym, w jego wymiarach: długości, szerokości i głębi, adekwatnych do wymiarów świata ${ }^{38}$. Jednak symbolizm Bonawentury mieści się w kategoriach ścisłego związku $\mathrm{z}$ historią, a nie w pojedynczo rozumianych metaforach czy znakach, podkreśla czas prawa natury wpisany we wnętrze historii świata i człowieka, analizuje następnie prawo litery, istotne dla norm społecznych, i prawo łaski Bożej wylanej z góry na całe stworzenie ${ }^{39}$. Analogicznie do kategorii prawa św. Bonawentura przedstawił sens krzyża w aspektach: kreacjonistycznym, antropologicznym i zbawczym. Historia człowieka według niego zawiera w swoim centrum Drzewo Życia, a wraz z nim górę Karmel ${ }^{40}$.

Bonawentura $\mathrm{w}$ swoim misterium krzyża nawiązał do poznania, które tak racjonalnie podkreślał za św. Tomaszem. Zarówno misterium Wcielenia, jak i misterium krzyża wymagają łaski, a ta jest rozumem oświeconym wiarą ${ }^{41}$. Ten właśnie istotny związek wiary-łaski-rozumu rozwinie później św. Jan od Krzy$\dot{z} \mathrm{a}^{42}$. W komentarzu do Ewangelii św. Łukasza Bonawentura opisał dramatyzm zjednoczenia przeciwieństw. Bóg stał się człowiekiem, Stwórca - stworzeniem, Nieskończony - chłopcem, Słowo - niemowlęciem, Wieczny - doczesnym ${ }^{43}$. Światło Boskie i oświecenie wprowadził na bazie rozumienia światła według teologii światła Pseudo-Dionizego Areopagity, jednakże połączył, według franciszkańskiej mistyki, światło z cieniem, sięgając do korzeni Starego Testamentu. Słowo Boże musiało przyciemniać się, aby stać się jasne dla człowieka. Chrystus porównywany jest do drzewa, które bierze swój początek z łona Maryi, a owocuje na krzyżu. W mistycznym traktacie Vitis mistica św. Bonawentura napisał wprost, że Chrystus narodził się z krzyżem i dla krzyża ${ }^{44}$.

37 Zob. M. Sulej, Św. Bonawentury teologia krzyża, Niepokalanów 1994.

${ }_{38}$ Zob. Św. Bonawentura, Pisma teologiczno-ascetyczne, t. 3: Breviloquium, dz. cyt., s. 213nn.

39 Zob. J. Ratzinger, Świętego Bonawentury teologia historii, tłum. E. I. Zieliński ofmConv, Lublin 2010.

$4^{\circ}$ Zob. E. Zieliński, Interpretacje filozofii św. Bonawentury, [w:] Św. Bonawentura. Życie i myśl, dz. cyt., s. 79-94.

${ }_{41}$ Zob. T. C. Niezgoda, Człowiek według nauki św. Bonawentury, [w:] Św. Bonawentura. Życie i myśl, dz. cyt., s. 279-296.

${ }^{42}$ Zob. K. Wojtyła, Zagadnienie wiary..., dz. cyt.

${ }^{43}$ Zob. T. C. Niezgoda, Człowiek..., dz. cyt.

${ }_{44}$ Zob. „Vitis Mystica seu Tractatus de Passione Domini”. Mistyczny krzew winny czyli traktat o Męce Pańskiej, tłum. i oprac. S. Kafel ofmcap., [w:] Św. Bonawentura, Pisma teologiczno-ascetyczne, dz. cyt., s. 163-203. Obszerne studium i komentarz zob. S. C. Napiórkowski, Chrystocentryzm myśli św. Bonawentury, „Roczniki Teologiczno-Kanoniczne” 21 (1974) z. 2, s. 6-39. 
W swojej pogłębionej antropologii wyjaśnił Wcielenie i pasję na krzyżu w sposób dwojaki: przyjęcie ciała (quantum ad substantiam) w rozumieniu natury ludzkiej oraz przyjęcie ciała cierpiącego i śmiertelnego (quantum ad defectum possibilitatis et mortalis) w rozumieniu egzystencjalnym. Chrystus dzięki wcieleniu przesadzony został z ogrodu rajskiego do ogrodu ziemskiego, aby przynieść więcej owoców. Jego życie podobne jest do ziarna, które w długim procesie staje się chlebem przemieniającym innych w siebie ${ }^{45}$. Święty Bonawentura przyrównał narodziny Chrystusa do źródła, do kwiatu, napełniającego wonią łask, do owocu dającego pokarm, do światła dającego życie. Chrystus jest przyrównany do drzewa, którego korzenie są miłością, pokora konarami, a gałęzie uzmysławiają stałe pragnienie rzeczy niebieskich. Kwiaty drzewa symbolizują życie religijne i moralne, liście to święte mowy, owoce są dziełami świętości, prawdy i dobra. Drzewo daje cień, który jest radosną wieścią, woń drzewa jest mocą modlitwy ${ }^{46}$.

Szczególne znaczenie w ugruntowaniu kultu krzyża i jego wyobrażeń plastycznych w formie drzewa życia, miał traktat Bonawentury Lignum Vitae, który w swojej koncepcji jest sumą tradycji wczesnego średniowiecza o krzyżu Chrystusa oraz franciszkańskiej praktyki modlitewnej. Zapisywany w kodeksach pod zmiennymi tytułami: Lignum Vitae, czasem Arbor crucis, Tractatus de arbore crucis, Contemplatio de passione Domini, łączy biblijne proroctwa o Mężu Boleści z ewangelicznymi przekazami o życiu, śmierci i zmartwychwstaniu Chrystusa ${ }^{47}$. Jego plastyczny, obrazowy język metafor miał służyć lepszemu zapamiętaniu, bowiem mnemonika w tekstach religijnych oraz w kazaniach była nader oczywista dla odbiorcy średniowiecznego. Istotnymi czynnikami kompozycji traktatu, oddziałującymi na wyobraźnię średniowiecznego odbiorcy, są bogate metafory przyrody: roślin, drzew, krzewów, kwiatów, źródeł w ich szerokim kontekście życia, kwitnienia, żywotności natury. W niej współistniał człowiek średniowiecza i w niej utożsamiał swoje życie biologiczne. Autor wprowadził obrazowo dynamiczną naturę drzewa, jego korzeni, konarów, liści, kwiatów, owoców, wreszcie jego korony pnącej się do nieba ${ }^{48}$.

Modlitwy i rozważania praktykowano w zakonnych oraz świeckich kręgach, nie tylko w pomieszczeniach zamkniętych, kaplicach, kościołach, oratoriach, ale zwłaszcza w przestrzeni otwartej. Zalecano, aby rozmyślać wszędzie: podczas

45 Zob. „Vitis Mystica seu Tractatus de Passione Domini”..., dz. cyt., passim.

${ }^{4}$ Zob. „Vitis Mystica seu Tractatus de Passione Domini”..., dz. cyt.

${ }^{47}$ Zob. Lignum Vitae, Drzewo życia, tłum. K. Żuchowski ofmbern, [w:] Św. Bonawentura, Pisma teologiczno-ascetyczne, dz. cyt., s. 259-284.

${ }^{8}$ Zob. Lignum Vitae, Drzewo życia, dz. cyt., passim. 
pracy na roli, w podróży, a także w ogrodzie. Nawiązywano wszak do eremickich wzorów życia.

Dzieło św. Bonawentury w swojej prostej strukturze obrazuje Krzyż męki w bezpośrednim oglądzie świata, doświadczanego na co dzień, ale także poznawanego dzięki lekturze Biblii. Liczne są nawiązania tekstów tego teologa do Księgi Rodzaju, opisu stworzenia i drzewa rajskiego ${ }^{49}$. Bonawentura rozwinął jego metaforyczną strukturę: korzeni, pnia, konarów, 48 liści, 12 owoców, włączając moralne przesłanie cnót życia. Stworzył precyzyjnie przygotowany scenariusz dla plastycznych wizualizacji, które niebawem zresztą podjęto. Popularyzacje traktatu i jego naśladownictwo przez różnych autorów spowodowały bądź uproszczenia, bądź rozwinięcia konkretnych aspektów pierwotnego bonawenturiańskiego przesłania. Popularny stał się tekst brata Ubertyna z Casale (1259-1329), mistyka, przedstawiciela skrajnego nurtu spirytualnego franciszkanów, Arbor vitae crucifixae Jesu, który wnosił wątki apokaliptyczne, a pierwotny franciszkański duch radości chrześcijańskiej, wynikający z nadziei, stał się emocjonalnym lękiem i poczuciem bezsilności ${ }^{50}$.

Nowoczesne myślenie kardynał zawarł już w Prologu, zachęcając wiernego do podjęcia wysiłku umysłowego i fizycznego, bowiem tylko wtedy może on pogłębić duchową kondycję, potrzebną do rozważań o Męce Pańskiej. Na tej drodze możliwe jest - jak naucza - aby rozwinęły się: „świeżości pamięci, bystrości umysłu i wielka miłość" ${ }^{1}$. Drzewo Życia wyrasta z ziemi w trzech rozgałęzieniach: na najniższym, na ziemi, Bóg stworzył człowieka, tam też jest miejsce pochodzenia i życia Chrystusa. W środkowej części pnia drzewa jest Męka Chrystusa, a w jego koronie - uwielbienie Chrystusa i Maryi, a także tron, na którym zasiadają Oblubieniec i Oblubienica. Forma tekstu św. Bonawentury jest osobowym dialogiem (wzorowanym na dialogach św. Augustyna), w który wplecione są cytaty z Biblii:

Przedstaw sobie w wyobraźni jakieś drzewo, którego korzeń byłby nawadniany $\mathrm{z}$ wiecznie tryskającego źródła, które zmienia się w wielką płynącą rzekę o czterech odnogach, które nawadniają cały raj (Est 10, 6 i Rdz 2, 10.6). Z pnia tego drzewa wyrasta ku górze dwanaście gałęzi pokrycia liśćmi, kwiatami i owocami. Liść tego drzewa byłby najskuteczniejszym lekarstwem $(\mathrm{Rz} 1,16)$, kwiat zaś wyróżniałby się

49 Zob. Lignum Vitae, Drzewo życia, dz. cyt.

5o Zob. F. Saxl, A spiritual encyclopedia..., dz. cyt.; przykłady diagramu drzewa proroków według Jaochima z Fiore: Ms 255A, Oxford, Corpus Christi College, s. 108, il. 27 a.

${ }^{51}$ Lignum Vitae, Drzewo życia, dz. cyt., passim. 
wspaniałą pięknością wszystkich kolorów i wszystkimi przyjemnymi zapachami, aby przyciągnąć i pokrzepić udręczone serca spragnionych. Owoce mają w sobie wszelką rozkosz i wszelki smak słodyczy (Mdr 16, 20). Jest to, oczywiście, owoc dziewiczego łona, a na drzewie krzyża doszedł Chrystus do dojrzałości, to znaczy do miłości ${ }^{52}$.

Wyjaśniając poznanie dobra i zła, Bonawentura podał przykład Adama, który wybrał drzewo poznania, a nie drzewo życia, czego nie można uniknąć - jak wyjaśnia autor traktatu - jeżeli nie postawi się wiary ponad rozumem, a pobożności ponad dociekliwością. Wszelkie doznania cielesne, własna słabość i cierpienie zyskają, gdy ponad nimi będzie roztropność. Przymiotami krzyża są: blask, światło i mądrośćs ${ }^{53}$.

Pierwszy Owoc krzyża, jak komentuje Bonawentura, Syn, pochodzi od Boga Ojca. Dalej autor pisze o kontemplacji „światła prostego, olśniewającego i w najwyższym stopniu tajemniczego, rodzi się odwieczny, równy i współistotny blask, który jest mocą i mądrością rodzącego" ${ }^{54}$. Święte narodzenie Jezusa, rozwinięte w Owocu III, wskazuje na pełnię czasu (według Ga 4, 4):

Archanioł Gabriel wysłany do Dziewicy zstąpił wraz z Duchem Świętym rozpalając Jej umysł i uświęcając ciało najdoskonalszą czystością. W jednej chwili zostało ukształtowane ciało, stworzona dusza, a zarazem jedno i drugie zostało zjednoczone $\mathrm{z}$ bóstwem w osobie Syna, aby zachowując właściwości obu natur był równocześnie Bogiem i człowiekiem ${ }^{55}$.

Maryja Matka Dziewica wyniesiona jest ponad rodzaj ludzki, co autor ujmuje słowami: „wielki był ten ogień zesłany z nieba, jak udzielona ochłoda, jak wlana pociecha” ${ }^{56}$ W tym rodzi się radość podobna tej wyśpiewanej w Magnificat; jak pisze Bonawentura, „Maryja idzie w góry, gdybyś mógł pójść z Panią swoją w góry".

Tajemnicę Wcielenia wprowadził autor do czasów realnych panowania cesarza Augusta, gdy nastąpiła „głęboka cisza” (Mdr 18, 14) i pokój, kiedy św. Józef, za sprawą Opatrzności Bożej, prowadził Panienkę z królewskiego rodu do miasta

52 Lignum Vitae, Drzewo życia, dz. cyt., s. 264-264.

53 Światło i oświecenie rozwija św. Bonawentura w Officium de Passione Domini. Zob. Oficjum o Męce Pańskiej, tłum. i oprac. S. Kafel ofmcap., [w:] Św. Bonawentura, Pisma teologiczno-ascetyczne, dz. cyt., s. 191-203.

54 Lignum Vitae, Drzewo życia, dz. cyt., s. 264.

55 Lignum Vitae, Drzewo życia, dz. cyt., s. 264-265.

${ }^{56}$ Lignum Vitae, Drzewo życia, dz. cyt., s. 265. 
Betlejem, wtedy Król Pokoju (1 Krn 22, 9) wyszedł z łona Dziewicy, jak oblubieniec ze swej komnaty (Ps 18,6$)^{57}$. Historia spleciona $\mathrm{z}$ mistyczną adoracją i duchowym zjednoczeniem $\mathrm{z}$ Dzieciątkiem jest nowym ujęciem $w$ interpretacji Bonawentury, zakończonej kontemplacją Eucharystii utrwalonej w wyobrażeniach franciszkańskiej sztuki.

Tajemnica Męki Chrystusa zamknięta jest w Owocach od v do viII, podobnie jak Narodzenie, rozpoczyna źródło wody żywej. Psalm 41, 2 (V, VI VII) sławi cnoty: Ufność w niebezpieczeństwach, Cierpliwość w ucisku, Wytrwałość $\mathrm{w}$ cierpieniu ${ }^{58}$. Z kulminacyjnym momentem umierania Chrystusa zjednoczone jest współcierpienie Maryi, która doznaje również przebicia serca strzałą. „Powiedział czule «Niewiasto oto syn Twój» [J 19, 26], dobrze wiedząc, jak bardzo ugodził Cię miecz Jego Męki” ${ }^{9}$. Po przebiciu włócznią następuje kontemplacja ciała Chrystusa, które pokryła krew jako nowa szata kapłańska. Autor wskazuje na analogie z szatą Józefa wrzuconego do starej cysterny (Rdz 37, 31-32): „Szata Chrystusa zbroczona krwią została wysłana Ojcu do rozpoznania i aprobaty" ${ }^{\text {. }}$. Jezus po Zmartwychwstaniu jest pięknem doskonałym, nazwany „najpiękniejszym kwiatem z korzenia Jessego" (Iz 11, 1). Natura Chrystusa zmartwychwstałego jest nadnaturalnym światłem.

W komentarzu św. Bonawentury do Sześciu dni stworzenia drzewo krzyża Chrystusa jest drzewem życia w raju. Chrystus jako Nowy Adam obmył swoją krwią i zasadził na krzyżu jako drzewie życia Kościół z odrodzoną ludzkością ${ }^{61}$. Drzewo krzyża jest drzewem ziemi w rozumieniu Kościoła, z którym autor powiązał Maryję Apokaliptyczną, otoczoną wieńcem z gwiazd dwunastu.

W traktacie o Mistycznym Krzewie Winnym teolog rozwinął dialog Maryi z Synem, Błogosławionym Kwieciem, Owocem Błogosławionej Gałązki, najczystszej Matki-Dziewicy ${ }^{62}$. Pielęgnacja krzewu przez przycinanie, okopywanie, ma formę dialogu, miłości mistycznej Maryi z Synem. Cierpiący Chrystus jest krzewem przywiązanym do słupa więzami posłuszeństwa. Bonawentura wskazuje na słowa proroka Izajasza: „Oto widzieliśmy Go, wdzięku ani piękności własnego

57 Zob. J. Ratzinger, Świętego Bonawentury teologia..., passim.

${ }_{58}$ Zob. Lignum Vitae, Drzewo życia, dz. cyt., s. 276.

59 Lignum Vitae, Drzewo życia, dz. cyt., s. 276.

6o Lignum Vitae, Drzewo życia, dz. cyt., s. 276.

${ }^{61}$ Zob. Bonawentura z Bagnoregio, Konferencje o sześciu dniach stworzenia albo oświecenia Kościoła, wydanie synoptyczne tekstu oryginalnego redakcji A oraz B z przekładem polskim, tłum., red. i wstęp A. Horowski of Mcap., Kraków 2008, passim.

${ }_{62}$ Zob. „Vitis Mystica seu Tractatus de Passione Domini”..., dz. cyt., s. 167. 
wyglądu nie miał w sobie i pragnęliśmy Go wzgardzonego i ostatniego z mężów Męża Boleści" (Iz 53, 2n) ${ }^{63}$.

Drzewo Życia w koncepcji Bonawentury nie jest tylko metaforą, znakiem lub sumą symboli. Jest programem skierowanym do wiernych w określonym czasie, w celu intensywnego myślenia, doświadczania wiary. Wyobrażenie Drzewa Życia obejmuje rzeczywistość nie tylko spełnioną w czasie przeszłym, lecz aktualną w życiu każdego człowieka. Poranione, wygięte w bólach członki ciała Chrystusa porównane są do natury członków drzewa: wygiętych korzeni, konarów, zwichrzonych liści. Jednocześnie, podobnie jak drzewo rozrasta się i pnie się ku górze, okaleczone, zdeformowane członki Zbawiciela stanowią realną rzeczywistość - zmysłową i duchową zarazem. Podobnie jak krzew - drzewo ma swoją wegetację, wzrost i owocowanie. W tej naturze drzewa zawiera się ciało mistyczne Chrystusa i, jak to obszernie wyjaśnia Bonawentura, ciało mistyczne Kościoła. Takiego krzyża doświadczał św. Franciszek w zatopieniu modlitewnym w kaplicy San Damiano, jak również w otwartej przestrzeni, w przyrodzie, gdzie doznawał mistycznego zjednoczenia poprzez stygmaty ${ }^{64}$.

Święty Bonawentura, czerpiąc ze źródła doświadczeń swojego mistrza, znając także kazania i pisma św. Antoniego z Padwy, na podstawie swojej wiary stworzył perspektywę teologiczną, opartą na przesłankach rozumu, wprowadzając do zwartego programu dydaktycznego oraz do kontemplacji mistycznej krzyża.

Pierwszą spośród zachowanych wizualizacją traktatu jest obraz Pacina di Buonaguidy Drzewo krzyża świętego, namalowany dla konwentu klarysek Monticelli fuori Porta san Frediano w latach $1305-1310^{65}$ (il. 3).

U stóp drzewa życia, na poziomie jego korzeni ukazane są sceny stworzenia Adama i Ewy i grzech rajski. Kompozycja nawiązuje do tekstów Bonawentury, zarówno komentarza do Sześciu dni stworzenia, jak i traktatu Lignum Vitae.

${ }_{63}$ Zob. „Vitis Mystica seu Tractatus de Passione Domini”..., dz. cyt., s. 168.

${ }^{64}$ Zob. Ch. Frugoni, Francesco..., dz. cyt., passim.

${ }^{65}$ Bonaventura 1274-1974. Il Dottore Serafico nelle raffigurazioni degli artisti, vol. 1, einl. P. Gerlach ofM, testo F. P. Pappini, Grottaferrata (Roma) 1974, s. 34. Ikonografia tego obrazu w kontekście teologii Bonawentury poddana została pod dyskusję, podczas której sformułowano dwa skrajne poglądy - A. Robba z 1936 roku i E. Guldana w 1968 roku. Ostatecznie jednak badacze nie podają $\mathrm{w}$ wątpliwość związku tekstów św. Bonawentury z wyobrażeniem Pacina di Bonaguidy. Istnieją inspiracje w malarstwie renesansowym i barokowym, wykazane na podstawie analizy ikonograficznej obrazu Francesca Raiboliniego, zwanego Francia, dla kościoła Santissima Annunziata w Bolonii (obecnie Bolonia, Pinacoteca Nazionale). Za: A. Galizzi, L’iconografia del Verbo Incarnato da Giovanni da Modena al Francia. Origine e sviluppo di una „Pittura sospetta”, [w:] Il luogo ed il ruolo della città di Bologna tra Europa continentale e Mediterranea. Atti del Colloquio C.I.H.A. 199o, a cura di G. Ferini, A. Emiliani, Bologna 1992, s. 114-115, przypis 13. 
Na surowym pniu drzewa ukazany jest Chrystus z wysoko uniesionymi ramionami, które nie odpowiadają tradycyjnemu układowi ramion poziomej belki. Podporządkowane są konarom drzewa, które w gęstym poszyciu roślinnym pną się ku górze, ku koronie. Tam usytuowany jest ptak, symbol zmartwychwstania - pelikan. Powyżej Drzewa Życia jest Jeruzalem niebieskie z Oblubieńcem i Oblubienicą, Maryją i Chrystusem Synem Bożym, siedzącymi na tronach w otoczeniu świętych. Na poszczególnych konarach wypisane są wersety zaczerpnięte $\mathrm{z}$ tekstu traktatu Lignum Vitae. Układ ciała Chrystusa podporządkowany został strukturze drzewa, jego sile wzrostu. Pomimo cierpienia ramiona Chrystusa również „wspinają się” ku górze, pokonując już na krzyżu śmierć. Całe ciało podporządkowane jest pionowemu układowi pnia i konarom drzewa.

Niezwykle zmonumentalizowaną formę $(1100 \times 1200 \mathrm{~cm})$ otrzymało wyobrażenie Drzewa Życia ucznia Giotta, Taddeo Gaddiego, datowane na rok 1360, na ścianie refektarza klasztornego konwentu Franciszkanów Świętego Krzyża we Florencji (obecnie Museo dell'Opera di Santa Croce) ${ }^{66}$ (il. 4). Obejmuje ono całą ścianę refektarza, stając się pierwszym scenicznym unaocznieniem Lignum Vitae według św. Bonawentury w dekoracji refektarzy, których program przebadał Andrew Ladis ${ }^{67}$. U stóp krzyża, najbliżej widza klęczy fundatorka fresku, Mona Vaggia Manfredi, pochowana w Santa Croce w roku $1345^{68}$. Ladis wskazał na źródła fresku i na znajomość tekstów franciszkańskich również przez Bonawenturę ${ }^{69}$. U podstawy całej kompozycji jest scena Ostatniej Wieczerzy, zaś po bokach cztery sceny, unaoczniające życie św. Franciszka, św. Ludwika z Tuluzy, św. Benedykta i Marii Magdaleny. Ostatnia Wieczerza jako pierwsza Eucharystia wskazuje na ciało mistyczne Chrystusa, cierpiącego na Drzewie Krzyża. Jego szczyt koronuje pelikan, a powyżej, na łuku tęczowym, widnieje święte Oblicze Chrystusa, dobrze znane w ikonografii franciszkańskiej. Pomiędzy tymi skrajnymi wymiarami, najniższym i najwyższym, rozrasta się wyobrażenie Arbor crucis. Ukazani zostali św. Franciszek i św. Bonawentura. Kompozycję uzupełniają zwoje

${ }^{66}$ Zob. Siena, Florence and Padua. Art, society and religion 1280-140o, vol. 1: Interpretative esseys, ed. D. Norman, London 1993, s. 25.

${ }_{67}$ Zob. A. Ladis, Taddeo Gaddi. Critical re-appraisal and catalogue raisonne, Columbia-London 1982, s. 171-173.

${ }_{68}$ Zob. A. Ladis, Taddeo Gaddi..., dz. cyt. Zagadnienie fundacji, mecenatu świeckich dla klasztorów określało wielkość i sposób komponowania fresków w pomieszczeniach klasztornych. Zob. B. Kempers, Kunst, Macht und Mäzenatentum. Der Beruf des Malers in der italienischen Renaissance, München 1989. Autor wskazuje na znaczenie autorstwa św. Bonawentury Żywotów św. Franciszka, co dawało podstawy dla mecenatu fundacji tablic i fresków (zob. s. 46nn).

69 Zob. A. Ladis, Taddeo Gaddi..., dz. cyt., passim. 
z wydarzeniami z życia, śmierci i zmartwychwstania Chrystusa. Są też postaci proroków i ewangelistów. Zgodnie z interpretacją św. Bonawentury historii krzyża, wpisującego się w aktualną historię człowieka, brakuje tam łotrów i szyderców po lewej stronie krzyża, natomiast stoją święci: Dominik, Franciszek i Ludwik z Tuluzy jako włączeni do życia wiecznego.

Najbliższym naśladownictwem fresku z Santa Croce jest kompozycja na ścianie bazyliki S. Maria Maggiore w Bergamo z roku 1347 wykonana przez mistrza Guglielmo $^{70}$. U stóp drzewa, niemal na jego korzeniach, klęczy św. Bonawentura. Ostatnim spośród zachowanych w tej serii kompozycji jest fresk w refektarzach konwentu franciszkańskiego pod wezwaniem św. Franciszka w Pistoi z drugiej połowy XIV wieku, z analogiczną postacią siedzącego pod krzyżem św. Bonawentury ${ }^{71}$.

Kompozycje malarskie, powstałe w XIV wieku w obrębie Toskanii, utrwaliły wizualne modele Drzewa Życia. Wpływ na to miała nauka św. Franciszka, potem ugruntowane teksty św. Bonawentury. Już w tych najwcześniejszych kompozycjach ukazany jest Chrystus na drzewie o szeroko rozłożonych, dekoracyjnie zwiniętych konarach i gałęziach, na których zwieszone niczym owoce medaliony ukazują sceny z życia Chrystusa i Maryi. Wyobrażenie młodego drzewa liściastego jest w sztuce zróżnicowane i nie zawsze jednorodne co do gatunku. Swoim kształtem liście nawiązują do oliwki, zaś konarami i sposobem zwiniętych gałęzi odzwierciedlają liście i krzewy winnego grona. Zawsze podkreślane jest bogactwo jego zmysłowej natury: pień osadzony jest na wypychających ziemię korzeniach, silnych i rozgałęzionych, zaś rozłożyste konary wskazują na żywotność i bogactwo natury, która pyszni się obfitością gałęzi z gęstwiną liści. Drzewo narzuciło sposób komponowania ramion Chrystusa. Krzyż ze zbitych belek pionowej i poziomej określił poziome napięcie ramion Chrystusa, co akcentowało mękę i śmierć Zbawiciela. Teraz ramiona są zwężone, wyciągnięte ku górze, ku koronie drzewa, gdzie sytuowany jest pelikan. Koegzystencja postaci Chrystusa z kompozycją drzewa, z układem konarów rozchodzących się z silnego pnia, skierowanych ku górze, oddaje efekt wspinania się całego ciała Chrystusa, wznoszenia się ku górze, jak przedstawiani byli pierwotni oranci. Ramiona są nieraz równoległe $\mathrm{z}$ tułowiem, tyle że uniesione ku koronie drzewa, na którym jest albo medalion z twarzą Chrystusa jako twarzą zmartwychwstałego Pana, albo pelikan, który rozpoznawany był jako znak życia wiecznego. Ten układ kompozycyjny ramion Chrystusa bliski jest wyobrażeniom Chrystusa wstępującego do nieba. Tamte

Zob. Bonaventura 1274-1974..., dz. cyt., s. 36.

${ }_{71}$ Zob. Bonaventura 1274-1974..., dz. cyt., s. 38 . 
sceny ukazywały Zbawiciela w białej szacie, tutaj jest On nagi, a Jego twarz wyraża ból, choć w jednym i drugim wypadku uniesiona jest ku Ojcu.

Obraz stanu cierpienia i umierania zastąpiony został procesem zanurzania się w cierpieniu, gdy jednocześnie cały tułów zdaje się pokonywać umieranie, wznosząc się ponad, przechodząc od śmierci krzyżowej do życia wiecznego. Owo przechodzenie jest jednocześnie stałym wznoszeniem się do Boga Ojca, do którego Syn kierował swoje słowa w modlitwie, interpretowane przez Żydów jako przywoływanie proroka Eliasza. W teologii były obszernie komentowane $(\text { Mt 27, 46; Mk 15, 34) })^{72}$.

W drugiej połowie xı wieku rozpowszechniły się rysunki i miniatorskie wyobrażenia Lignum Vitae, ukazujące Symbolum Apostolicum, diagramy drzewa cnót, drzewa mądrości Bożej, które analizował w swoim dogłębnym studium Franz Saxl ${ }^{73}$. W najstarszych zachowanych manuskryptach kompozycje nawiązują do XII-wiecznych diagramów drzewa cnót i wad, genealogicznego drzewa Chrystusa Radix Jesse, które kopiowano w XVI- i XVII-wiecznych alegorycznych diagramach drzewa w celu propagowania różnorodnych, nieraz bardzo skomplikowanych przekazów religijnych ${ }^{74}$.

Misternie pod względem artystycznym, w znacznie rozbudowanym programie ikonograficznym, który w xIv wieku wyobrażano na freskach lub tablicach, ukazane zostały dwa drzewa: Drzewo Życia i Drzewo Śmierci na fresku w kaplicy Sant Abbondio w bazylice San Petronio w Bolonii (il. 5). Ich twórca, malarz Giovanni da Modena (Giovanni di Pietro Falloppi; 1409-1455), był znany w Modenie i Bolonii. Stąd złożenie zamówienia na tak kunsztownie przemyślaną kompozycję jest dowodem sprawności malarskiej i współpracy z duchownym autorytetem. Rozłożyste drzewo $\mathrm{z}$ alegoriami cnót nasuwa analogię z diagramem Lignum Vitae, ukazanym na karcie Missale Casanatensis (fol. 16r) z drugiej połowy xIII wieku, z postacią św. Bonawentury siedzącego u podstawy drzewa ${ }^{75}$. Artysta na fresku w katedrze San Petronio wyraźnie zaakcentował w pierwszym znacze-

72 Prorok Eliasz jest wielokrotnie przypominany w pismach św. Bonawentury, zwłaszcza w konferencjach. Znamienny jest także fakt szczególnie ożywionej jego ikonografii we włoskim Trecento, zwłaszcza w Sienie i Florencji. Szersza prezentacja ikonografii proroka Eliasza w kontekście sztuki karmelickiej w średniowieczu jest opracowywana przez autorkę niniejszej pracy.

73 Zob. F. Saxl, A spiritual encyclopedia..., dz. cyt., passim.

${ }^{74} \mathrm{Na}$ temat diagramów drzewa jako alegorii cnót istnieje wyczerpująca literatura. Z nowszych prac por. J. Le Goff, Un mystère de l'art dévoilé. Le sang du christ et le fruit de la vigne, [w:] J. Le Goff, Unlong Moyen Âge, Paris 2004, s. 226-237.

75 Zob. I. Kloten, La Fortuna di S. Petronio. Il patrono della città e la politica delle immagini, [w:] Il luogo ed il ruolo..., dz. cyt., s. 87-101. 
niu ikonografię Chrystusa na Drzewie Życia. Malarz wykształcony w Modenie, znający dobrze spuściznę Giotta, powiększył swoją kompozycję, wprowadzając przesłanie moralne w interpretacji teologii Bonawentury; wyraźny jest kontekst tekstu komentarza do Sześciu dni stworzenia.

Było to potrzebą ówczesnego Kościoła dużego, znaczącego miasta, u progu nowożytności, mającego aspiracje zarówno ekonomiczne, jak i naukowe nie tylko w obrębie prowincji Lombardii i Emilii. Malarz przedstawił dwie paralelne kompozycje, unaoczniające Stary i Nowy Testament. Wyraźnie ożywił postaci w ich warstwie cielesnej i przekazie emocjonalnym. Taka jest natura drzewa. Dorodne, rozległe w swoich konarach i liściach, stanowi oś koncentrującą postaci Starego i Nowego Przymierza. Po prawej stronie drzewa stoi Maryja, po lewej przedstawiciele Starego Testamentu z Adamem i Ewą. Chrystus wznosi się na rozkwitających gałązkach, powyżej pnia drzewa, który oplata wąż z ludzką głową o kobiecej twarzy. Jasne jest przesłanie tej kompozycji, wskazującej na Maryję Nową Ewę i Chrystusa Nowego Adama. Jest to drzewo Stworzenia i Zbawienia. Druga paralelna kompozycja drzewa jest unaocznieniem zła i grzechu. Sposób zakomponowania konarów i liści przypomina profetyczne drzewo z kodeksu Corpus Cristi College w Oksfordzie, które, jak wykazał Pächt, nawiązuje do licznych pierwowzorów w miniatorstwie francuskim około roku $1200^{76}$.

Aby w pełni zrozumieć tę nowatorską kompozycję i postrzegać ją w perspektywie znaczenia krzyża według św. Bonawentury, spójrzmy pokrótce na najważniejsze fakty związane z historią i kultem relikwii krzyża, Grobu Chrystusa oraz męczenników w Bolonii.

Etruskie miasto zdobyte przez Odoakra, potem Bizantyńczyków, zachowało, wzorem tradycji ambrozjańskiej, pamięć męczenników, których groby znaleziono na cmentarzu. Święty Ambroży, jadąc do Mediolanu, zatrzymał się tutaj w 387 roku. Miasto z całym regionem Emilii jako południowej prowincji Lombardii należało do Mediolanu, którego zwierzchnikiem był święty biskup. W Bolonii, analogicznie do Rzymu i Mediolanu, powstały poza murami miasta kompleksy grobowe świętych męczenników. W kompleksie św. Szczepana, nazwanym Świętym Grobem Jerozolimskim jako Loca Sancta - Grób Chrystusa, wybudowanym w IV/v wieku, przez całe średniowiecze czczono święty Krzyż nie tylko jako cząstkę relikwii krzyża, ale przypominanie całej Golgoty i Grobu Pańskiego. Był też tutaj żywy kult męczenników: Nabora, Feliksa, Vitalisa

${ }^{76}$ Za: F. Saxl, A spiritual encyclopedia..., dz. cyt., s. 106-108. 
i Agricoli z VI wieku ${ }^{77}$. W XIII stuleciu powstawały kościoły i zakony w służbie mieszkańcom rozrastającego się miasta: franciszkanie w 1254 roku, dominikanie w 1267, serwici - bazylika Santa Maria dei Servi, w której kult związany był ze świętem Zwiastowania Najświętszej Panny Maryi. Dla tej bazyliki Cimabue namalował swoją Maestà - Madonnę na tronie z Dzieciątkiem. Karmelici służyli najpierw mieszkańcom contado, okolicznym osadom podmiejskim, zajmując mniejsze oratoria, zanim otrzymali kaplicę w centrum miasta. Wskazuje się, że karmelici około roku 1260 zajmowali jedną z kaplic romańskiego kościoła św. Piotra, przebudowanego następnie w stylu gotyckim ${ }^{78}$. Po rozbudowie gotyckiej kościoła pierwotna kaplica Karmelitów włączona została do nowej fary miejskiej San Petronio. Budowa nowego kościoła San Petronio trwała długo, między 1340 a 1390 rokiem $^{79}$. W nowej bazylice miasta pierwsze prace freskowe wykonał Giovanni z Modeny. Pozwolenie na budowę własnego kościoła opodal centrum miasta, w pobliżu Palazzo del Comune i Palazzo del Podestà, otrzymali karmelici od władz miejskich w roku $1308^{80}$. Mieli zatem swoje dwa miejsca San Petronio i własny kościół Santa Maria degli Angeli - dla spełniania funkcji liturgicznych i duszpasterskich.

Miasto w tym okresie stało się centrum kształcenia młodzieży zakonnej dominikanów, karmelitów i franciszkanów. Szybko rozwijały się fakultety: prawniczy, teologiczny i medycyny. Wyobrażenie Drzewa Życia w kaplicy San Petronio w Bolonii świadczy o ambitnym fundatorze, znającym dobrze wczesne palestyńskie tradycje wyobrażenia krzyża jako Lignum Vitae, ale i współczesne traktaty franciszkańskie św. Bonawentury, popularne w środowisku uniwersyteckim, a także w codziennej pobożności.

Karmelici swoją działalność w obrębie sztuki ugruntowywali zrazu w swoim ukryciu, cechującym pierwotne życie eremickie. Jednak już w XIII i XIV wieku wskazuje się na dążenie, aby kształtować własny program, który legitymizowałby ich własną duchowość, silnie związaną z kultem Maryi, niezwykle popularnym w większości zakonów działających w Europie, szczególnie w Italii. Karmelici potrzebowali wyrazić własną religijność, którą szczycili się jako znacznie starszą aniżeli zadomowione w miastach klasztory braci mniejszych i dominikanów. Jednak ci mogli swój autorytet religijny potwierdzić własnymi świętymi założycielami,

77 Zob. A. M. Mattelucci, Bologna, [w:] Enciclopedia dell'Arte Medioevale, vol. 3, Roma 1992, s. $576-587$.

${ }_{78}$ Zob. A. M. Mattelucci, Bologna, dz. cyt., s. 584-585.

79 Zob. A. M. Mattelucci, Bologna, dz. cyt.

8o Zob. A. M. Mattelucci, Bologna, dz. cyt. 
a nawet męczennikami, na co wskazuje w badaniach Bram Kempers ${ }^{81}$. Karmelici mieli natomiast Maryję w nazwie swojego zakonu i w kulcie oraz proroka Eliasza, który był znaną postacią w średniowiecznej sztuce łacińskiej. Teraz jednak zakon karmelitów uczynił go swoim patronem obok Najświętszej Maryi Panny z góry Karmel. Na podstawie zachowanych dokumentów lub dzieł sztuki wymienia się Sienę, miasto Maryi, jako duży konwent karmelitów, powstały pomiędzy 1301 a 1309 rokiem. Wskazuje się na początki tworzenia tam programu ikonografii karmelickiej ${ }^{82}$. Tam też powstawały kompozycje ze świętym Eliaszem; jego zwycięstwo nad Baalem było znaczące dla Europy czasów krucjat ${ }^{83}$. W Sienie zachowały się pierwsze wyobrażenia świętych eremitów z góry Karmel i świętych karmelu z obszaru Italii. Tam był czczony zaraz po śmierci w 1308 roku, zanim został kanonizowany w roku 1457, Albert Siculus ${ }^{84}$. Jego kult rozwijany był w kościele Serwitów, Santa Maria dei Servi, gdzie został pochowany ${ }^{85}$.

Oryginalny program ikonograficzny potwierdza obraz Matki Bożej wraz z predellą, na której ukazane były historie karmelitów w Ziemi Świętej. Zamówiony u najwybitniejszego wówczas malarza Piotra Lorenzettiego przez ówczesnego przeora brata Piotra, uświadamia aspiracje zakonu, aby w swoim kręgu fundować dzieła wybitne i, jak na owe czasy, kosztowne ${ }^{86}$. Dojrzały program ikonografii maryjnej oraz historii Karmelu, prowadzącej do proroka Eliasza, jest dowodem świadomego wyboru typu obrazowego Maryi, która była w Sienie obecna w wielu prototypach, co zostało dogłębnie przebadane. Nowym aspektem obrazu jest historia karmelitów w predelli. Tam umieszczano historie świętych patronów, np. św. Ludwika z Tuluzy w obrazie Simone Martiniego. Częściej jednak było tam miejsce na Oblicze Chrystusa lub Ukrzyżowanie w centrum predelli, zaś na sceny z życia Chrystusa - z prawej i lewej strony ${ }^{87}$. W tym miejscu nie możemy rozwinąć tej ważnej problematyki, jaką stanowią predelle nastaw ołtarzowych w Italii. Zagadnienie to przebadał i zawarł w dużej monografii historyk sztuki

${ }^{81}$ Zob. B. Kempers, Kunst..., dz. cyt., s. 31-10o (rozdział Die Bettelorden).

${ }_{82}$ Zob. D. Norman, Siena and the Virgin. Art and politics in the Late Medieval City State, New Haven 1999, s. 205, 235.

${ }_{3}$ Zob. E. Friedman ocD, The Latin hermits of Mount Carmel, Roma 1979, passim (Institutum Historicum Teresianum. Studia).

${ }^{84}$ Zob. E. Friedman ocD, The Latin hermits..., dz. cyt., s. 238.

${ }_{5}$ Zob. E. Friedman ocD, The Latin hermits..., dz. cyt.

${ }^{86}$ Zob. H. Van Os, Sienese Altarpieces 1213-1460, Groningen 1984; J. Cannon, Pietro Lorenzetti and the history of the Carmelite Order, „Journal of the Warburg and Courtauld Institutes” 50 (1987), s. $18-28$.

87 Zob. J. Cannon, Pietro Lorenzetti and the history of the Carmelite Order, dz. cyt., s. 18-28. 
Arno Preiser ${ }^{88}$. Istotne są sceny upamiętniające historię zakonu w Palestynie, po raz pierwszy obrazowo sformułowaną $\mathrm{w}$ predelli nastawy ołtarzowej, zamówionej dla kościoła Karmelitów w Sienie. Ta świadomość historycznej kontynuacji od czasów wczesnochrześcijańskich potwierdzała znaczną dominację karmelitów nad zakonami żebraczymi, a także dowodziła, że kult Maryi z Góry Karmel sięgał czasów znacznie wyprzedzających to nabożeństwo w Europie. Wskazuje się na zastane w Italii obrazy, które we wczesnym etapie fundacji karmelitańskich kontynuowały włoski typ ikony, jak to potwierdza dokument z 1280 roku, w którym wymieniono obraz (mozaika) Maryi - Santa Maria del Carmine we Florencji. Jest podkreślone zmysłowe piękno Maryi ymagines [...] bella e di bello colore ze świętymi: Agnieszką, Janem Ewangelistą i Janem Chrzcicielem. Obraz ten był umieszczony na fasadzie średniowiecznego kościoła Karmelitów we Florencji, całkowicie jednak przebudowanego ${ }^{89}$.

Obrazy Maryi powstałe dla kościołów i kaplic karmelitańskich w Italii xiv wieku kontynuowały tutejsze modele Maryi z Dzieciątkiem, które w swoich prototypach potwierdzają związek z tradycjami wschodnimi w odmianie znanej jako Mater decor Carmeli $i^{90}$. Wzorce tego typu wyobrażenia Maryi z Dzieciątkiem upowszechniane były według nazw własnych, jak np. Madonna Bruna z Neapolu, albo w Rzymie Santa Maria in Traspontina ${ }^{91}$. Model tronującej Maryi z Dzieciątkiem miał swój prototyp (przyjmując rożne na ten temat zdania badaczy) w wyobrażeniach na drobnej plastyce, powstałej w Palestynie, podobnie jak Ligum Crucis ${ }^{92}$. Ampułki na oliwę z cyny lub szkła, kosztowne naczynia srebrne lub z kryształu przewożono z Bizancjum do Europy w długim okresie średniowiecza. Formy tej transmisji wzorów ikonograficznych przebiegały poprzez oficjalne kontakty kościelne, zakonne, polityczno-monarsze oraz drogami kupiecko-handlowy-

${ }_{88}$ Zob. A. Preiser, Das Entstehen und die Entwicklung der Predella in der italienischen Malerei, Hildesheim-New York 1973. Badacz wskazuje na fragmentaryczny stan zachowania obiektu i na jego duże walory artystyczne. Około roku 1600 obraz został przemalowany ponownie, odnowiono go w okresie międzywojennym (zob. s. 275). Por. P. Bacci, Dipinti inediti e sconosciuti di Pietro Lorenzetti, Bernardo Daddi etc. in Siena e nel suo contado, Siena 1939, s. 35-68.

${ }^{89}$ Fundacja romańsko-gotycka w roku 1268, budowana aż do 1476. Przebudowywana stopniowo w okresie Cinque- i Seicento, zniszczona pożarem w 1771 roku; ponownie odrestaurowana. E. B. Garison (Italian Romanesque panel painting. An illustrated index, Florence 1949) odnalazł $\mathrm{w}$ dokumentach zakonnych informację o istnieniu kilku cennych obrazów Maryi, fundowanych pomiędzy drugą połową XIII a XV wiekiem.

$9^{\circ}$ Zob. E. B. Garison, Italian Romanesque panel painting..., dz. cyt., s. 126.

${ }_{91}$ Zob. J. Cannon, Pietro Lorenzetti..., dz. cyt., s. 20-21.

${ }_{92}$ Zob. A. Grabar, Christian iconography. A study of its origins, London 1968, passim; E. B. Garison, Italian Romanesque panel painting..., dz. cyt., passim. 
mi. Ten rodzaj wymiany i przenikania do Europy palestyńskich przedmiotów dewocji był niezwykle intensywny. Najsilniej ugruntowane kontakty handlowe, obok kościelno-zakonnych, mieli Włosi w Palestynie: głównie w Tyrze, Akkce, Jaffie, Trypolisie ${ }^{93}$. Znane są oficjalne przywileje i prawne regulacje Królestwa Jerozolimy dla Pizy, Wenecji, Genui, Lukki, Sieny, które gwarantowały swobodne przemieszczanie się, prawne bezpieczeństwo korzystania z oficjalnych szlaków handlowych oraz wymianę handlową.

Udział karmelitów w kulturze religijnej średniowiecznej Italii, podobnie jak badane znaczenie zakonu w innych częściach Europy, potwierdza nowy fenomen w stosunku do zakonów powstałych w Europie od czasów św. Benedykta. Zrastając się swoimi korzeniami z Ziemią Świętą, sięgnęli oni do czasów proroka Eliasza, zarazem jednocząc się z miejscami świętymi życia i śmierci Chrystusa. Identyfikacja z Ziemią Świętą była nie tylko memorialna, ale i fizyczna, dosłownie rozumiana poprzez górę Karmel i miejsca w Palestynie. Była życiem wraz z tamtejszymi wizualizacjami kultu Maryi i Chrystusa, potwierdzonymi już od początku v wieku. Przybywając do Europy, karmelici asymilowali się z tutejszymi uwarunkowaniami, wnosząc jednocześnie własny etos życia.

Święty Bonawentura dobrze znał Palestynę i pisma teologów wschodnich, znał także wyobrażenia krzyża jako Drzewa Życia, które stamtąd przyszły do Europy. Będąc uformowanym duchowo franciszkaninem, jednocześnie wykształconym teologiem, przygotował podstawę intelektualną, która rozwinęła pierwotne uproszczone kompozycje Krzyża Życia do idei Lignum Vitae i pojawiła się w nowożytnej mistyce Karmelu, w pismach Jana od Krzyża i Teresy z Ávila. Jak dalece zaowocowała w kunsztownych formach krzyża w nowożytnej sztuce, pokazują badania ojca prof. Wanata.

Na zakończenie warto przytoczyć przykład pięknego krucyfiksu z kości słoniowej z kościoła Ojców Karmelitów w Warszawie, obecnie seminaryjnego (il. 6). Jego forma analogiczna jest z serią krucyfiksów z kości słoniowej z XVII wieku, które przechowywane są w polskich i obcych zbiorach (il. 7). Idea bonawenturiańskiego Lignum Vitae jest przekazana nowożytnym językiem, tudzież kunsztem artystycznym w uniesionych ramionach, w ciele wypracowanym jako członki „żywe”, zjednoczone z krzyżem w postaci nieobrobionych belek ${ }^{94}$.

${ }_{93}$ Zob. M. L. Favreau-Lilie, Die Italiener im Heiligen Land vom ersten Kreuzzug bis zum Tode Heinrichs von Champagne (1098-1197), Amsterdam 1989, s. 445-450.

${ }_{94}$ Za perfekcyjne wykonanie fotografii i za zgodę na jej reprodukcję w niniejszej pracy wyrażam gorące podziękowanie panu Januszowi Rosikoniowi. 


\section{Bibliografia}

Bacci P., Dipinti inediti e sconosciuti di Pietro Lorenzetti, Bernardo Daddi etc. in Siena e nel suo contado, Siena 1939.

Baudrillart A., Dictionnaire d'histoire et de géographie ecclésiastiques, vol. 11, Paris 1949.

Bieniarzówna H., Piotrowski A., Sanktuarium Maryjne w kościele O. Karmelitów na Piasku, Kraków 1983.

Bonaventura 1274-1974. Il Dottore Serafico nelle raffigurazioni degli artisti, vol. 1, einl. P. Gerlach of M, testo F. P. Pappini, Grottaferrata (Roma) 1974.

Bonawentura z Bagnoregio, Konferencje o sześciu dniach stworzenia albo oświecenia Kościoła, wydanie synoptyczne tekstu oryginalnego redakcji A oraz B z przekładem polskim, tłum., red. i wstęp A. Horowski ofmcap., Kraków 2008.

Borenius T., An Early Sienense crucifixion, „Burlington Magazine” 56 (1930), s. 123-156.

Cannon J., Pietro Lorenzetti and the history of the Carmelite Order, „Journal of the Warburg and Courtauld Institutes" 50 (1987), s. 18-28.

Colombo A., Le ampolle metalliche della basilica di Monza, „Rivista di Monza” 1937, s. 21-31.

Dobrzeniecki T., Legenda o Secie i drzewie życia w sztuce średniowiecznej, „Rocznik Muzeum Narodowego w Warszawie" 10 (1966), s. 165-204.

Dobrzeniecki T., Maiestas Domini w zabytkach polskich i obcych z Polska zwiazanych, „Rocznik Muzeum Narodowego w Warszawie” 17 (1973), s. 5-264.

Favreau-Lilie M. L., Die Italiener im Heiligen Land vom ersten Kreuzzug bis zum Tode Heinrichs von Champagne (1098-1197), Amsterdam 1989.

Friedman E., The Latin hermits of Mount Carmel, Roma 1979 (Institutum Historicum Teresianum. Studia).

Frugoni Ch., Francesco e l'invenzione delle stimmate. Una storia per parole e immagini fino a Bonaventura e Giotto, Torino 1993.

Galizzi A., L'iconografia del Verbo Incarnato da Giovanni da Modena al Francia. Origine e sviluppo di una „Pittura sospetta”, [w:] Il luogo ed il ruolo della città di Bologna tra Europa continentale e Mediterranea. Atti del Colloquio C.I.H.A. 199o, a cura di G. Ferini, A. Emiliani, Bologna 1992, s. 114-115.

Gambosco V., Per conoscere sant'Antonio. La vita - Il pensiero, Padova 1990.

Gilbert C., Some special images for carmelites, [w:] Image and religions, eds. T. Verdon, J. Handerson, New York 1990, 1990.

Gilson E., Die Philosophie des hl. Bonaventura, Freiburg 1960.

Gilson E., Historia filozofii chrześcijańskiej w wiekach średnich, tłum. S. Zalewski, Warszawa 1966.

Goff J. Le, Un mystère de l'art dévoilé. Le sang du christ et le fruit de la vigne, [w:] J. Le Goff, Unlong Moyen Âge, Paris 2004, s. 226-237. 
Grabar A., Ampoules de Terre Sainte, „Zeitschrift für Kunstgeschichte” 51 (1988), s. 34-56. Grabar A., Christian iconography. A study of its origins, London 1968.

Grabar A., Les Ampoules de Terre Sainte Monza-Bobbio, Paris 1938.

Hendriks R., La Succession hereditaire Elie le prophete, Bruges 1956.

Itineraria Hierosolymitana et descriptiones Terrae Sanctae, vol. 1, a cura di T. Tobler,

A. Molinier, Geneve 1870.

Itineraria Hierosolimitana, saeculi IV-VIII, a cura di P. Geyer, Vindobonae 1898.

Jan od Krzyża doktor Kościoła, Droga na Górę Karmel. Noc ciemna. Żywy płomień miłości. Pieśń duchowa, Kraków 1999.

Karmelita Bosy, Ideał i duch Karmelu, przekład z francuskiego, wyd. M.R.K.B., Kraków 1946.

Kempers B., Kunst, Macht und Mäzenatentum. Der Beruf des Malers in der italienischen Renaissance, München 1989.

Kloten I., La Fortuna di S. Petronio. Il patrono della città e la politica delle immagini, [w:] Il luogo ed il ruolo della città di Bologna tra Europa continentale e Mediterranea. Atti del Colloquio C.I.H.A. 199o, a cura di G. Ferini, A. Emiliani, Bologna 1992, s. 87-101.

Ladis A., Taddeo Gaddi. Critical re-appraisal and catalogue raisonne, Columbia-London 1982

Leclercq H., Ampoules a eulogies, [w:] Dictionnaire d'Archéologie Chrétienne et Liturgie, vol. 2, Paris 1924.

Lignum Vitae, Drzewo życia, tłum. K. Żuchowski of mвern, [w:] Św. Bonawentura, Pisma teologiczno-ascetyczne, Warszawa 1978, s. 259-284.

Mattelucci A. M., Bologna, [w:] Enciclopedia dell'Arte Medioevale, vol. 3, Roma 1992, S. $576-587$.

Monaco G., Santa Maria del Carmine detta „La Bruna”, Naples 1975.

Mottoni B. Faes de., LIllusione dei sensi? Angeli e sensi in Bonaventura e in Tommaso d'Aquino, „Micrologus. Natura, Scienze e Società Medievali” 10 (2002), s. 294-312.

Napiórkowski S. C., Chrystocentryzm myśli św. Bonawentury, „Roczniki Teologiczno-Kanoniczne" 21 (1974) z. 2, s. 6-39.

Niezgoda T. C., Człowiek według nauki św. Bonawentury, [w:] Św. Bonawentura. Życie i myśl, red. C. Napiórkowski, I. Zieliński, Warszawa 1976, s. 279-296.

Norman D., Siena and the Virgin. Art and Politics in the Late Medieval City State, New Haven 1999.

Nowe życie w Chrystusie, tłum. K. Żuchowski ofmbern, [w:] Św. Bonawentura, Pisma teologiczno-ascetyczne, Warszawa 1978, s. 303-311.

Officium de Passione Domini. Oficjum o Męce Pańskiej, tłum. i oprac. S. Kafel of mcap., [w:] Św. Bonawentura, Pisma teologiczno-ascetyczne, Warszawa 1978, s. 191-203.

Os H. Van, Sienese Altarpieces 1213-1460, Groningen 1984. 
Płonka-Bałus K., Antyfonarz z roku 1397 w Bibliotece oo. Karmelitów na Piasku w Krakowie. Ze studiów nad iluminatorstwem czeskim przełomu XIV i XV wieku, „Folia Historiae Artium" 27 (1981), s. 35-60.

Praśkiewicz Sz. T., Duchowość Maryjna w Świętym Karmelu, Poznań 2011.

Preiser A., Das Entstehen und die Entwicklung der Predella in der italienischen Malerei, Hildesheim-New York 1973.

Ratzinger J., Świętego Bonawentury teologia historii, tłum. E. I. Zieliński of Mconv, Lublin 2010.

Romanini H., Assisi, [w:] Enciclopedia dellarte Medievale, vol. 1, Roma 1989.

Romanini H., Il Medioevo. Storia dell'Arte Italiana, vol. 2, Firenze 1988.

Róg R., Karmelici. Duchowość. Historia, Kraków 1997.

Ruth K., Bonaventura, Köln 1956.

Sabatini A., Origini e Antichità della Provincia Toscana dei Carmelitani, „Analecta Ordinis Carmelitanum" 16 (1949), s. 183-220.

Saxl F., A spiritual encyclopedia of the Later Middle Ages, "Journal of the Warburg and Courtauld Institutes" 5 [1942], s. 82-134.

Septuaginta czyli Biblia Starego Testamentu wraz z księgami deuterokanonicznymi i apokryfami, tłum., przypisy i wstęp ks. R. Popowski, Warszawa 2014.

Smet J., Historia Zakonu Braci Najświętszej Maryi Panny z Góry Karmel, t. 1-4, Kraków 1986.

Steenberghen van F., Filozofia wieku XIII, tłum. I. Zieliński, Lublin 1991.

Sulej M., Św. Bonawentury teologia krzyża, Niepokalanów 1994.

Trajdos T., Fundacja Klasztoru Karmelitów Trzewiczkowych pw. Bożego Ciała w Poznaniu. Kult Eucharystyczny króla Władysława Jagiełty, „Poznańskie Studia Teologiczne” 5 (1984), s. 317-362.

Trajdos T., U zarania Karmelitów w Polsce, Warszawa 1993.

Veuthey L., Filozofia chrześcijańska św. Bonawentury, tłum. E. I. Zieliński of Mconv, Niepokalanów 1996.

„Vitis Mystica seu Tractatus de Passione Domini”. Mistyczny krzew winny czyli traktat o Męce Pańskiej, tłum. i oprac. S. Kafel ofmcap., [w:] Św. Bonawentura, Pisma teologiczno-ascetyczne, Warszawa 1978, s. 163-203.

Wanat B., Matka Boska Szkaplerzna w Czernej, Kraków 1988.

Wanat B., Zakon Karmelitów Bosych w Polsce. Klasztory Karmelitów i Karmelitanek Bosych 1605-1975, Kraków 1979.

Wanat B., Zakon Karmelitów Bosych w Polsce, t. 1-2, Kraków 1988.

Weitzmann K., Loca Sancta and the representational arts of Palestine, „Dumbarton Oaks Papers" 28 (1974), s. 32-55.

Wojtyła K., Zagadnienie wiary w dziełach św. Jana od Krzyża, [w:] Jan Paweł II o świętych Karmelu, przygot. Cz. Gil ocD, Kraków 1986. 
Zieliński J., Herb Karmelu. Historia, symbolika, duchowe przesłanie, Kraków 2001.

Zieliński E., Interpretacje filozofii św. Bonawentury, [w:] Św. Bonawentura. Życie i myśl, red. C. Napiórkowski, I. Zieliński, Warszawa 1976, s. 78-96.

\begin{abstract}
Abstrakt
Pokaźna spuścizna badawcza ojca karmelity Bienignusa Wanata, profesora historii sztuki, inspiruje do dalszych badań - aby wyjaśnić plastykę powstałą w obrębie karmelu w średniowieczu, która była kontynuowana w czasach nowożytnych. W niniejszej pracy zaprezentowany został motyw krzyża jako Lignum Vitae, znany najwcześniej z drobnej plastyki Palestyny obszaru życia pierwszych karmelitów. Podejmujemy próbę związania tej formy krzyża utrwalonej na dewocyjnych przedmiotach przywożonych do Europy z Ziemi Świętej, z tradycją kultu zarówno Maryi, jak i Krzyża. Wskazuje się na pierwsze eremy w Palestynie, następnie na osiedlenie się karmelitów w Italii w połowie XIII i w XIV wieku. Istnieją związki eremickiego życia karmelitów z pierwotnymi formami życia franciszkanów w Italii, zwłaszcza w Umbrii. Podejmowane były w nauce główne kierunki pobożności, następnie kształcenia uniwersyteckiego karmelitów w Italii w XIII i początku XIV wieku. Wskazano na ich ścisły związek z nauką św. Tomasza z Akwinu i pobożnością dominikańską, którą kontynuowali wielcy mistycy karmelu w XVII wieku. W niniejszej pracy wskazuje się na nurt pobożności franciszkańskiej i związek z kontemplacją Krzyża jako Drzewa Życia, którego forma asymilowana była poprzez import z Palestyny ampułek na świętą oliwę oraz innych przedmiotów wotywnych. Taki motyw krzyża znany w ikonografii franciszkańskiej został zaasymilowany również do pobożności karmelu choć wielość konkretnych dzieł sztuki pochodzi z czasów nowożytnych, co potwierdza np. krucyfiks z kościoła pokarmelickiego w Warszawie. Pisma i traktaty św. Bonawentury czytano i kontemplowano w środowisku karmelickim Teksty te ugruntowały motywy krzyża w sztuce.
\end{abstract}

\title{
Słowa kluczowe
}

ampułki z Ziemi Świętej, Lignum Vitae, eremici, karmelicka plastyka w średniowieczu, św. Bonawentury traktaty w obrazach Drzewa Życia, karmelici-franciszkanie, powinowactwo sztuki 


\begin{abstract}
The relations of St. Bonaventure's theology of the cross with the Carmelite mysticism. In the realm of Franciscan and Carmelite artistic affinity exemplified by the chosen works of art from the $14^{\text {th }}$ and the early $15^{\text {th }}$ centuries
\end{abstract}

Rich research legacy of Carmelite Father Bienignus Wanat, an art history professor, is the motivation of further studies carried out to explain plastic arts created within the Carmelite Order in the Middle Ages and continued till modern times. In the present paper the motif of the cross as Lignum Vitae, which was known the earliest from Palestinian small plastic works of art in the first Carmelites' area of living, has been presented. We are making an attempt to relate this form of the cross, depicted on religious objects which were brought to Europe from the Holy Land, to the tradition of both St. Mary's worship and that of the Cross. The first hermitages in Palestine followed by the settlement of the Carmelites in Italy in the $13^{\text {th }}$ and $14^{\text {th }}$ centuries have been pointed out. There are certain relations between the Carmelites' hermit lives and the original forms of Franciscan life in Italy, Umbria especially. The research has been done on the main directions of piety and university education of Carmelites in Italy in the $13^{\text {th }}$ and at the beginning of the $14^{\text {th }}$ century. Their close relation to the teaching of St. Thomas Aquinas and Dominican piety, continued by the most renowned Carmelite mystics in the $17^{\text {th }}$ century, has been pointed out.

In the present paper the mainstream of Franciscan piety has been pointed out and its relation with the contemplation of the Cross as The Tree of Life, the form of which was assimilated by importing ampoules for the holy oil or other votive items from Palestine. Such a motif of the cross, well-known in Franciscan iconography, was also assimilated in Carmelite piety, although the abundance of specific work of arts dates back to the modern era, which is confirmed, e.g. by a crucifix from a fromer Carmelite church in Warsaw. St Bonaventure's writings and treaties were read and contemplated in the Carmelite milieu. Those texts established the motifs of cross in art.

\title{
Keywords
}

ampoules from the Holy Land, Lignum Vitae, hermits, Carmelite plastic arts in the Middle Ages, st. Bonaventure's treaties in the pictures of The Tree of Life, Carmelites-Franciscans, artistic affinity 

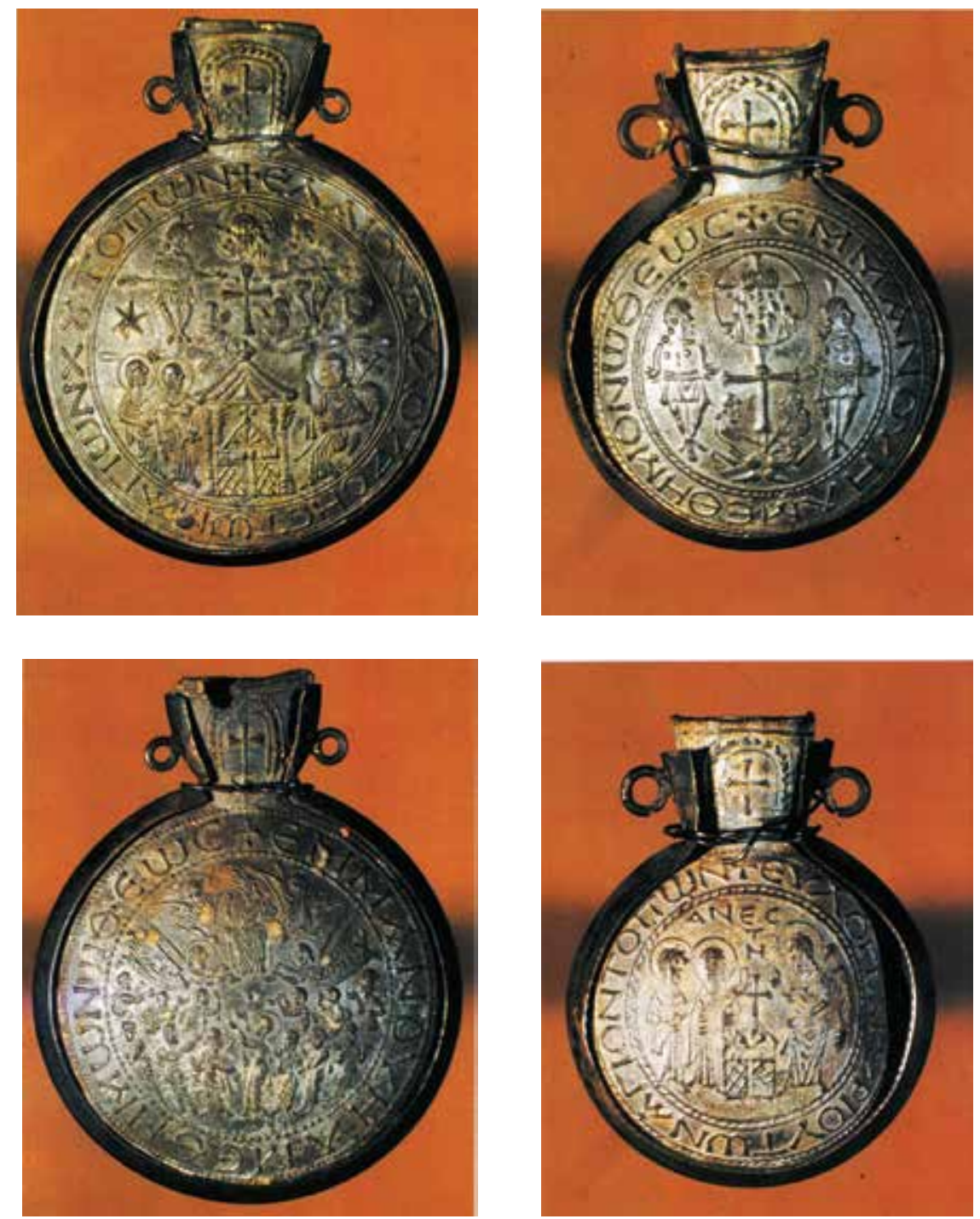

1-2. Ampułki z Monza, repr. za: Splendori di Bisanzio.

Testimonianze e riflessi d'Arte e cultura bizantina nelle chiese d'Italia, Milano 1991 


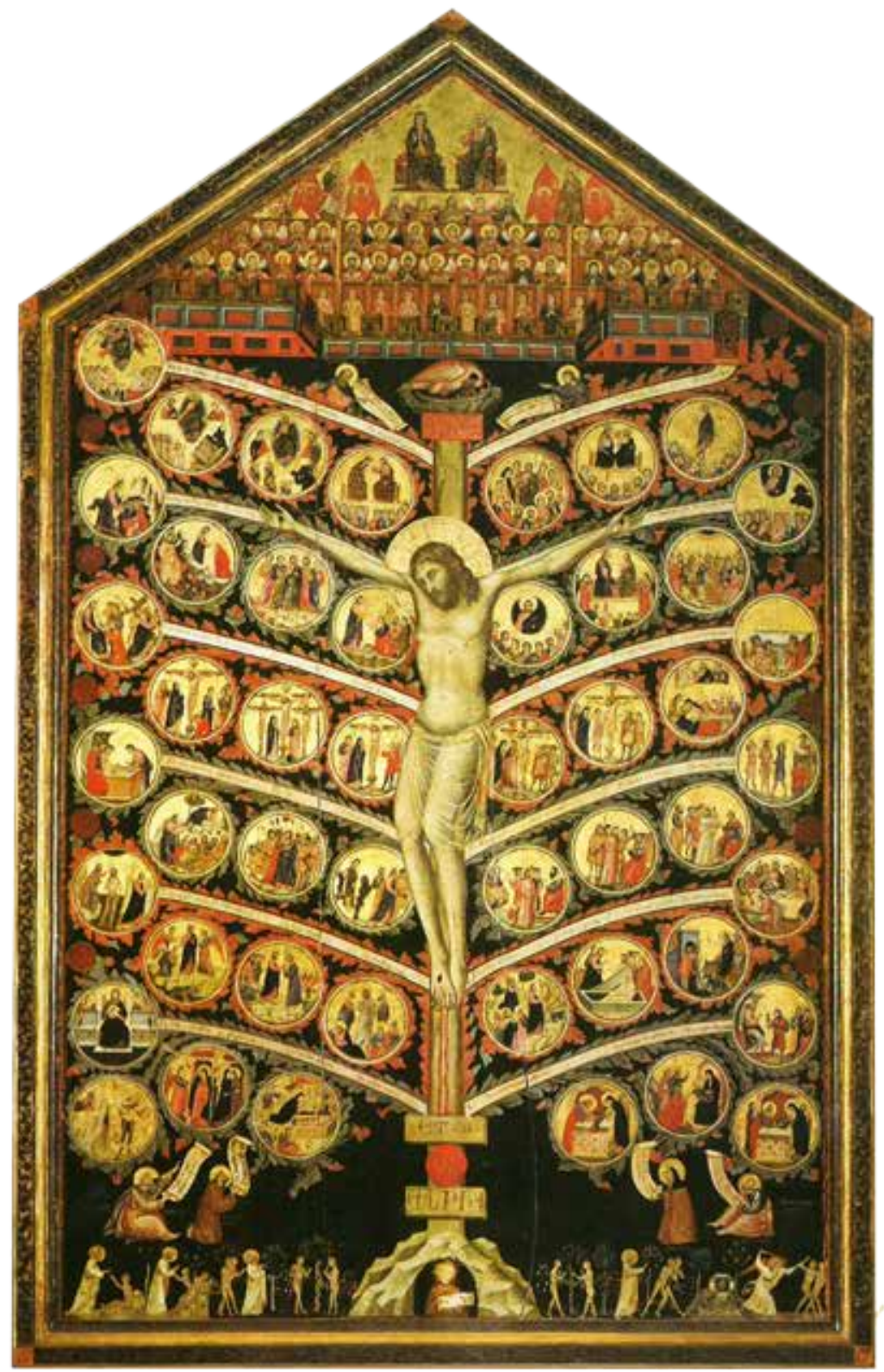

3. P. di Bonaguida, Drzewo Życia, Florencja, Galleria dell'Accademia.

Fot. Galleria dell'Accademia 


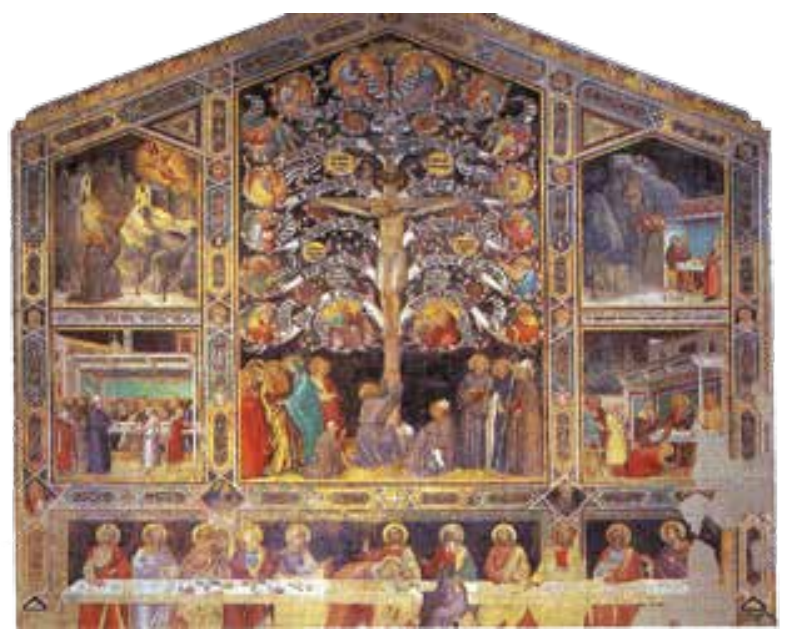

4. T. Gaddi, Drzewo Życia, fresk z refektarza Santa Croce, Florencja, obecnie Museo dell'Opera di Santa Croce. Fot. Museo dell'Opera di Santa Croce

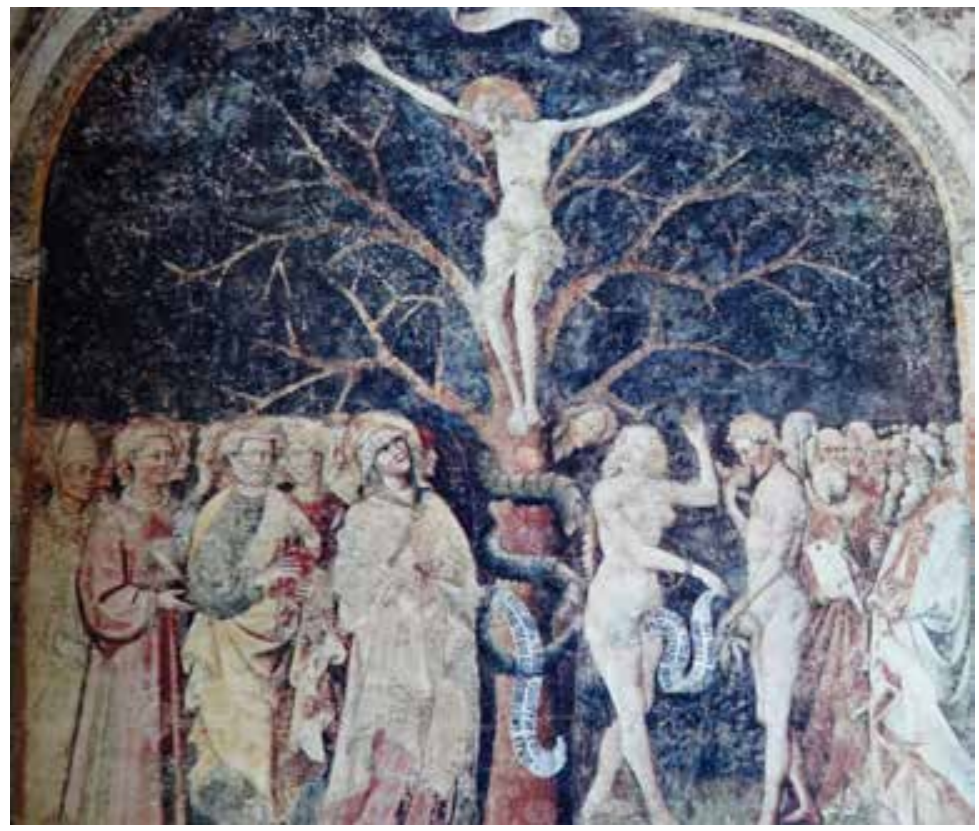

5. G. da Modena, Drzewo Życia, fresk z bazyliki San Petronio w Bolonii, kaplica San Abbondio. Fot. kościół San Petronio 


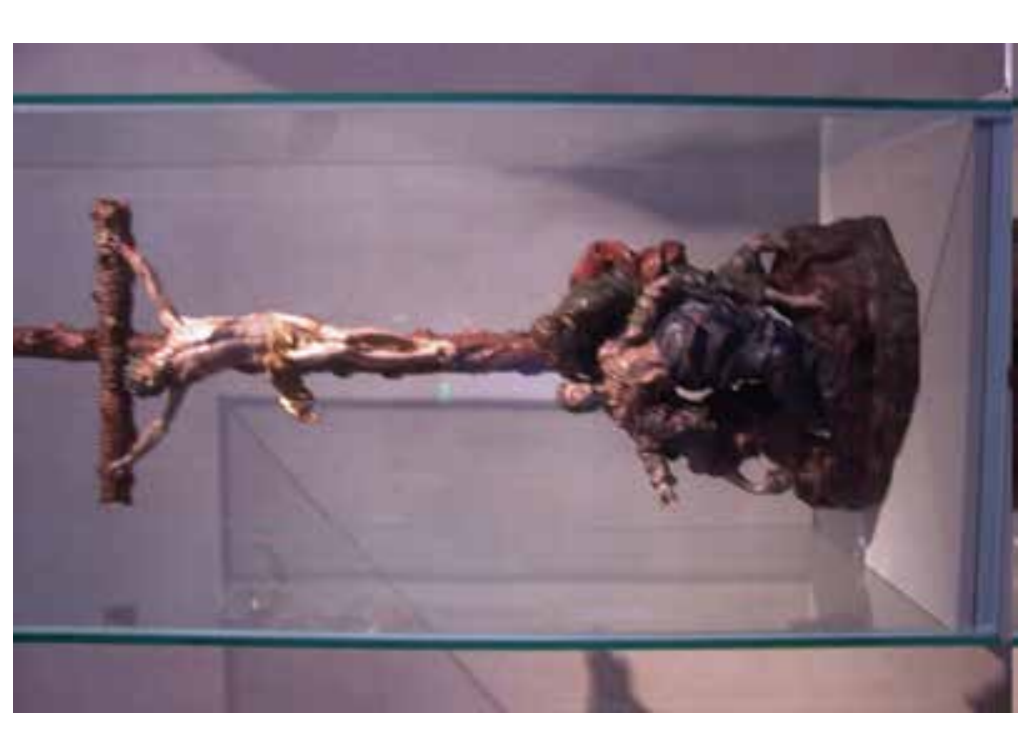

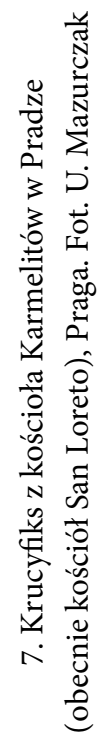
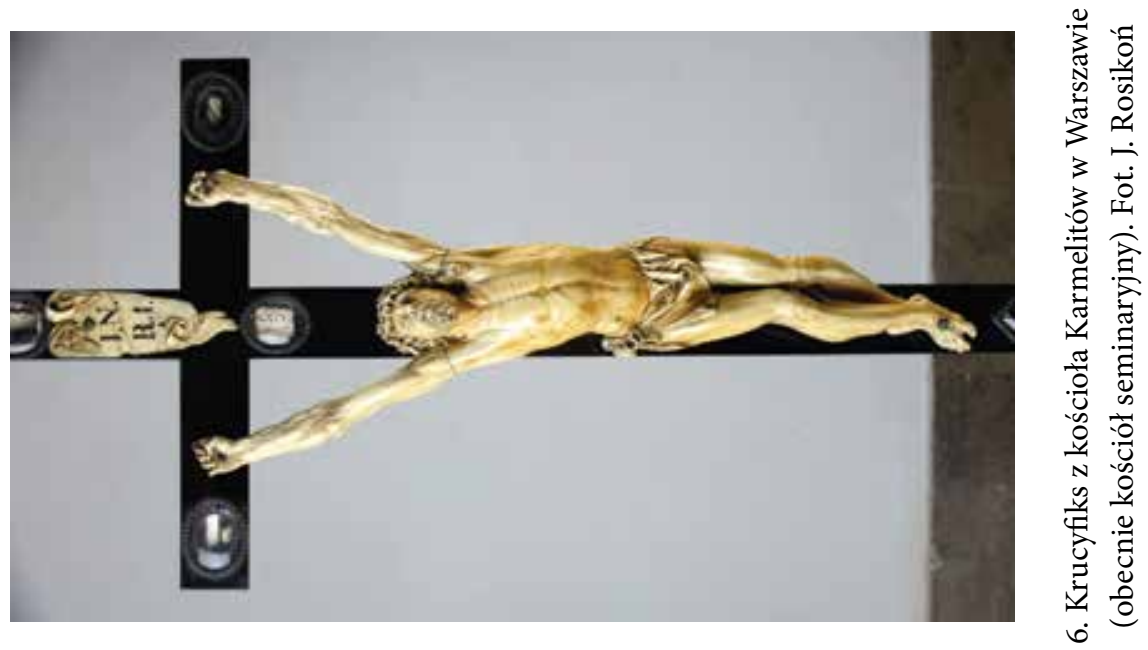